\title{
Do Economic Freedom and Entrepreneurship Impact Total Factor Productivity?
}

Bjørnskov, Christian; Foss, Nicolai Juul

Document Version

Final published version

Publication date:

2010

License

CC BY-NC-ND

Citation for published version (APA):

Bjørnskov, C., \& Foss, N. J. (2010). Do Economic Freedom and Entrepreneurship Impact Total Factor

Productivity? Center for Strategic Management and Globalization. SMG Working Paper No. 8/2010

Link to publication in CBS Research Portal

\section{General rights}

Copyright and moral rights for the publications made accessible in the public portal are retained by the authors and/or other copyright owners and it is a condition of accessing publications that users recognise and abide by the legal requirements associated with these rights.

\section{Take down policy}

If you believe that this document breaches copyright please contact us (research.lib@cbs.dk) providing details, and we will remove access to the work immediately and investigate your claim. 


\section{DO ECONOMIC FREEDOM AND ENTREPRENEURSHIP}

IMPACT TOTAL FACTOR PRODUCTIVITY?

Christian Bjørnskov

Nicolai J. Foss

SMG WP 8/2010

September, 2010 
SMG Working Paper No. 8/2010

September, 2010

ISBN: 978-87-91815-61-4

Center for Strategic Management and Globalization Copenhagen Business School

Porcelænshaven 24

2000 Frederiksberg

Denmark

www.cbs.dk/smg 


\title{
DO ECONOMIC FREEDOM AND ENTREPRENEURSHIP IMPACT TOTAL FACTOR PRODUCTIVITY?
}

\author{
Christian Bjørnskov \\ Department of Economics \\ Aarhus School of Business, Aarhus University \\ Hermodsvej 22, DK-8230 Åbyhøj, \\ Denmark; ChBj@asb.dk \\ Nicolai J. Foss \\ Center for Strategic Management and Globalization \\ Copenhagen Business School \\ Porcelainshaven 24, DK-2000 Frederiksberg, \\ Denmark; njf.smg@cbs.dk \\ and \\ Department of Strategy and Management \\ Norwegian School of Economics and Business Administration \\ Breiviksveien 40, N-5045, Bergen, Norway
}

September 17, 2010

\section{Acknowledgements}

We are grateful to Morten Bennedsen, Niclas Berggren, Dan Johansson, Peter G. Klein, Keld Laursen, Pierre-Guillaume Méon, Martin Ågerup and participants in the third Beyond Basic Questions workshop for helpful comments on earlier versions, and to Kasper Krogshave and Claus Vistesen for excellent research assistance.

Keywords: Total factor productivity, freedom variables, self-employment

JEL Code: 043, 047, 057 


\title{
DO ECONOMIC FREEDOM AND ENTREPRENEURSHIP \\ IMPACT TOTAL FACTOR PRODUCTIVITY?
}

\begin{abstract}
The economics of growth has shown that countries not only grow by deploying higher levels of inputs to production, but also by better allocating whatever resources are at their disposal and by introducing productivity-enhancing innovations. We proffer arguments as to why and how entrepreneurship as well institutions of liberty (i.e., economic freedom, including the rule of law, easy regulations, low taxes and limited government interference in the economy) positively impact total factor productivity (TFP): These institutions allow entrepreneurial experimentation with the combination of factors to take place at low transaction costs. We test these ideas on a unique panel data set derived from Compendia, World Bank data and the Fraser Institute's economic freedom data. We find that while entrepreneurship positively impacts TFP, the marginal contribution of entrepreneurship to TFP is strongest in economies with substantial government activity.
\end{abstract}




\section{INTRODUCTION}

Differential national growth was at the center of economics at the beginnings of the discipline: Adam Smith famously argued that the "obvious and simple system of natural liberty" was strongly conducive to growth and thus placed institutions as the heart of economic progress and growth (Holcombe, 1998). The right institutions lead to an increasing division of labor, which in turn prompt innovation and productivity advances carried out by enterprising firms and individuals. Later economists shifted the attention away from institutions and entrepreneurship and towards labor growth and capital accumulation as the main drivers of growth, with unexplained technological progress as an add-on, albeit an essential one. Solow's (1956) seminal work is, of course, exemplary of this. However, his empirical finding (Solow, 1957) that the main part of the growth was caused by exogenous factors stimulated growth accounting as a sub-field in economics, and made endogenizing technological progress a pressing issue on the research agenda of the profession, although for various fundamentally technical reasons this took essentially three decades to achieve (Lucas, 1988; Romer, 1990; Jones, 1995).

The overall insight emerging from this body of work is that one of the most important reasons why countries differ in terms of development is rooted in their different levels of productivity: Countries not only grow by deploying more inputs to production, but also by better allocating whatever resources are at their disposal and by introducing productivity-enhancing innovations (Temple, 1999). The notion of "total factor productivity" (henceforth, TFP) captures this. Klenow and Rodriguez-Clare (1997) show that differences in TFP drive the main part of growth differences in a cross-country sample from 1960 to 1985. In turn, an emerging literature has begun exploring the "deeper" determinants of growth, that is, which factors cause differences in TFP. We link up with this literature and argue that the incentives defined by the institutional matrix of society will significantly influence TFP.

It has long been recognized that the institutional matrix impacts economic growth by influencing the labor/leisure tradeoff, structuring the incentives to expend effort and accumulate capital, and so on (e.g., North, 1990; Glaeser, La Porta, de Silanes, and Shleifer, 2004). Less interest has been devoted to understanding how it impacts TFP, that is, output changes that are not caused by changes in the "traditional" inputs of labor and capital. We proffer arguments as to why "economic freedom variables" influence TFP (cf. also Gwartney, Lawson, and Holcombe, 1999; Klein and Luu, 2003; Méon and Weill, 2005). We specifically argue that economic freedom, including the rule of law, easy regulations, low taxes and limited government interference in the economy, allows entrepreneurial experimentation with combining productive factors to take place in a low transaction 
costs manner. Such institutions of liberty thereby increase the aggregate elasticity of substitution, an important mechanism in the growth process. ${ }^{1}$

To assess these issues empirically, we rely on a variety of data sources. We follow Nyström (2009) in measuring entrepreneurial activity as harmonized self-employment rates for OECD countries from the Compendia database (van Stel, 2005); we use the well-known economic freedom indices (Gwartney and Lawson, 2009) to ask which elements of economic policy making and the institutional framework affect the supply of entrepreneurship in societies; and we finally draw on data from Barro and Lee (2001) and the Penn World Tables to construct data on a standard measure of TFP, and to measure openness, and so on. The combination of these datasets is unique in the literature.

\section{THEORETICAL BACKGROUND}

\section{Total Factor Productivity}

The understanding of the growth process in economics has historically involved a fundamental debate between those who stress the driving role of capital accumulation (Jorgenson \& Griliches, 1967; Lucas, 1988) and those who stress "technology" (Solow, 1956, 1957) and other factors that fall outside the accumulation of capital and improvement of and increases in the supply of human capital (cf. Aghion and Howitt, 1998; Hulten, 2001). According to the latter camp, the growth process is fundamentally one of improvements in TFP. Thus, disparities in wealth and productivity across nations are driven by "residual factors." Klenow and Rodriguez-Clare (1997), Hall and Jones (1999) and Parente and Prescott (2000) present evidence that most of the extant cross-country differences in output per worker is driven by differences in total factor productivities.

It has long been recognized that TFP is about much more than "technology", understood as recipe-like advances in scientific knowledge (Erken, Donselaar, and Thurik, 2008; Acs, Braunerhjelm, Audretsch, and Carlsson 2009). Since the initial identification of the "unexplained" causes of growth (Solow, 1956), significant attention has been devoted to R\&D as a driver of growth (e.g., Romer, 1990; Coe and Helpman, 1995). However, R\&D itself does not drive TFP; innovations that emerge from R\&D do (Acs et al., 2009). In turn, innovations are introduced by enterprising firms and individuals (Schumpeter, 1939; Baumol, 1993).

Although it stands to reason that the "entrepreneur is the prime mover of progress" (Kirzner, 1980), it is only very recently that growth economists have explicitly begun to model and measure

\footnotetext{
${ }^{1}$ That economic freedom variables are significantly associated with the level of entrepreneurship in an economy has been documented in a number of recent studies (Kreft and Sobel, 2005; Bjørnskov and Foss, 2008; Nyström, 2009).
} 
the entrepreneurial function. ${ }^{2}$ Foss, Foss, Klein and Klein (2007) argue that the dominance of the production function framework in post-war economics is a main cause of the neglect of the entrepreneur: If production factors are assumed to be homogenous within categories (e.g., Solow's "shmoo" capital) and production is always at the efficient frontier, there is simply very little to do for the entrepreneur. In actuality, factors of production are heterogeneous (Lachmann, 1956), how they should be combined is often by no means obvious, and requires technical and commercial processes that are in a sense experimental in nature (Hayek, 1968; Matsusaka, 2001). ${ }^{3}$ The optimum combination of inputs is not a datum. Moreover, what is at any moment the optimum combination will change as a result of changes in underlying scarcities. Given this, some matching process is required. Hayek (1968) forcefully argues that given the dispersed nature of knowledge in society, competition performs such matching in a superior way compared to the known alternatives.

Ongoing processes of industrial dynamics, that is, processes of mergers, divestments, spin-offs, new firm formation, etc. reflect such experimentation. On the aggregate level, they amount to the economy tracking its (moving) production possibility frontier, and therefore to improving the efficiency with which resources are utilized. For example, Foster, Haltiwanger, and Krizan (1998) estimate that competitive dynamics through reallocation of productive assets account for about $50 \%$ of the aggregate productivity growth. Moreover, hampering the automatic restructuring of industries in developed countries has been shown to imply a penalty in terms of forgone growth (Audretsch Carree, van Stel, and Roy, 2003). These processes are driven by entrepreneurs alert to seizing hitherto overlooked possibilities of profit (Kirzner, 1997). Also, entrepreneurs that are alert to knowledge produced abroad and import it in the hope of realizing a profit opportunity contribute to national catching-up (Fagerberg, 1987), that is, the national production possibility frontier tracking those of more advanced nations. The upshot of the above is a hypothesis that entrepreneurship positively contributes to TFP.

\section{Institutions}

\footnotetext{
${ }^{2}$ Entrepreneurship has also been included in models inspired by endogenous growth theory (Erken et al. 2008).Audretsch et al. (2006) and Acs et al. (2004) argue that a primary function of entrepreneurship is to perform a search within the available knowledge stock and pick those parts of this stock that can give rise to new products or processes. Typically, this function is carried out by upstart firms. There is still little empirical work on this. Temple's (1999) overview of empirical work on growth contains no mention whatsoever of entrepreneurship. Part of the reason is that data-sources that allowed for cross-national comparisons have been virtually non-existent. The first data set (i.e., the Global Entrepreneurship Monitor) that allows for consistent cross-national comparisons was initiated as late as 1999.

${ }^{3}$ From such a perspective, the conventional distinction in the growth literature between factor accumulation and productivity as differential drivers of growth may be overdrawn: entrepreneurship underlies both, as capital is not a passive accumulation of Shmoo capital least in the private sector of the economy), but is deployed to actual production by enterprising individuals in the hope of capturing a profit opportunity (Holcombe, 1998).
} 
Economic historians have long pointed to crucial role that institutions play in the growth process (as neatly summarized in North, 1990), and the economics growth literature is increasingly following suit. Thus, important work suggests that different institutions are differentially impact growth, and although factors such as human capital are by no means unimportant (Glaeser et al., 2004; Acemoglu, 2005), some scholars (e.g., Rodrik, Subramaniam, and Trebbi., 2004) go so far as to claim that "institutions rule" in the sense that institutional quality overwhelms other determinants of growth. The main reason to expect institutional quality to affect growth positively is that it entails decreased transaction costs through reduced uncertainty of economic transactions and productivityenhancing incentives. As North explains, "[t]he major role of institutions in a society is to reduce uncertainty by establishing a stable (but not necessarily efficient) structure to human interaction. The overall stability of an institutional framework makes complex exchange possible across both time and space" (North, 1990: 6). In turn, higher certainty implies lower transaction costs, as the costs of entering into, bargaining, monitoring and protecting contractual and ownership rights are reduced (Barzel, 2005). This increases the expected value of projects, and hence make them more likely to be undertaken. By offering incentives for productive behaviour, efficient institutions stimulate individuals to engage in those actions where the private return is close to the social return (Demsetz, 1967). The two effects, reducing uncertainty and providing efficient incentives, are, in our view, jointly necessary and sufficient for institutional quality.

Higher certainty and incentives for productive behavior may arise on the basis of many institutional characteristics, not least those relating to the protection of private property rights. Some examples of such characteristics are: generality (that equals are treated equally), transparency in public decision-making, accountability in public decision-making and, importantly, an expectation that the institutions will be properly implemented and enforced. In such a setting, agents are more willing to engage in economic transactions. Thus, by giving political and economic actors incentives to behave honestly and predictably, high quality institutions help ensure that consequences of economic undertakings are more easily foreseen and that incentives stimulate productive rather than unproductive behavior (cf. Baumol, 1996). This contributes to economic growth.

\section{Freedom Variables}

The above abstract identification of those institutional characteristics that are conducive to efficient allocation as well as (we argue later) growth are closely related to what may be called “freedom variables." Thus, stable, well-defined property rights and the rule of law are traditionally central in classical liberal thought (e.g., Hayek, 1973). Conversely, economists have typically treated economic freedom as a composite construct that includes such components that all ultimately boil down to the security and extent of property rights, but include, for example, the freedom to save, to 
change jobs, to devise contracts, to keep income, etc. In particular, many scholars, and certainly those with a leaning towards classical liberalism (e.g., Friedman, 1962), have used the size of government in a broad sense - that is, the extent to which the government intervenes in the economy through government consumption, redistribution through transfer schemes, public investments, and marginal taxation - as an adequate, or at least reasonable, measure of economic freedom (e.g., Gwartney, Lawson, and Holcombe, 1999; Carlsson and Lundström, 2002).

An important item in an economic freedom measure arguably is sound money (Friedman, 1962), in particular the rate and variability of inflation. Anticipations of future relative prices are important in general for economic decision makers. Inflation, and particularly erratic inflation, "jams" the signalling effects of relative prices (Friedman, 1977). This is particularly troublesome in for those agents who undertake intertemporal allocation, namely entrepreneurs.

Another relevant "freedom variable" is the degree of openness to international trade and investment. Larger trade flows through a country may arguably imply more access to international price signals, allowing potential entrepreneurs to take advantage of not only national but also international opportunities. In addition, freedom to invest could, as is often found in empirical studies, increase the rate of technology adoption (cf. Wacziarg, 2001; Madsen, 2008). In addition, the absence of capital restrictions also implies easier access to international capital markets.

Finally, public regulation is an important item in an economic freedom measure (Kirzner, 1985). Excessive regulations impose burdens on all firms, not the least start-ups, that may imply prohibitive start-up costs. In addition, Baumol (1996) makes the point that individuals operating in heavily regulated economic environment may have larger gains from engaging in rent-seeking activities within the public sector (i.e., "destructive entrepreneurship") than in real economic activities (Capelleras, Mole, Greene, and Storey, 2007).

\section{Transmission Mechanisms: Institutions, Freedom Variables, and Total Factor Productivity}

In the recent surge of interest in the institutional determinants of growth, it is arguable that the micro-foundations of the link between institutions and growth have been somewhat neglected. As Wennekers and Thurik (1999: 27) suggest, more attention should be devoted to the

economic agents who link the institutions at the micro level to the economic outcome at the macro level. It remains veiled how exactly institutions and cultural factors frame the decisions of the millions of entrepreneurs and of entrepreneurial managers working with large companies.

While this issue remains of general interest in the context of growth theory, it partakes of particular significance in the context of understanding why institutions (and policies, broadly conceived), 
including freedom variables, drive TFP: Increases in TFP result from new processes, new modes of organization, ways of better allocating resources to preferred uses, and so on.

Given this, the flexibility (i.e., costliness) with which such changes can be carried out becomes highly important. In terms of production theory, this flexibility is captured by notion of the elasticity of factor substitution (Klump and De La Grandville, 2000), that is, the the percentage change in factor proportions due to a change in marginal rate of technical substitution (e.g., in the extreme example of a Leontieff technology, the elasticity is 0). At the level of a country, the (aggregate) elasticity of substitution is a measure of the flexibility of the economy, for example, with respect to reacting to external shocks (Acquilina et al., 2006: 204). It is also clear that the elasticity of substitution is affected by a number of forces; for example, an argument for liberalizing such trade, is that such trade may expand the possibility set with respect to input combinations that a country's entrepreneurs face. Hence, it becomes less likely that a single factor will act as a brake on the growth process (Ventura, 1997).

This suggests that the elasticity of substitution goes beyond being a purely technical issue (or a “deep parameter”). In fact, recent work (particularly Miyagiwa and Papageorgiou, 2006) argues that the aggregate elasticity of substitution should be seen as endogenous (but see already Arrow et al., 1961). Although certain inherent technical constraints imply that factors will never be perfect substitutes, we argue that the aggregate elasticity of substitution is to a large extent endogenous to institutional variables, specifically to freedom variables. In turn, a high elasticity of substitution implies high factor productivity, because it means that resources are more easily allocated to highly valued uses, new modes of organization and new processes are more easily implemented and so on.

Underlying the positive impact on factor productivity of high elasticity of substitution are a high degree of certainty in dealings, and therefore low transaction costs of searching for contract partners, bargaining, monitoring and enforcing contracts. Huge literatures in economic history, on intellectual property rights, and on innovation stress the importance for entrepreneurial activity at the micro level and economic development at the macro level of property rights being well-defined and enforced (e.g., North, 1990: Glaeser et al. 2004; Mokyr, 2006). Well-defined and enforced property rights reduce the transaction costs of carrying out the commercial experimentation, that is, entrepreneurship (Rosenberg, 1992), because well-defined property rights usually imply that contracting costs are relatively low, and it is thus less costly to search for, negotiate with and conclude bargains with owners of those inputs that enter into entrepreneurial ventures. Well-defined and enforced income rights imply that the risk of undertaking entrepreneurial activities is reduced, which may also stimulate the supply of entrepreneurship. If so, it can be expected that institutional features, such as the quality of regulations and the judicial system, positively affect TFP. 
Similar reasoning applies to the freedom variable of sound money (Friedman, 1962), in particular the rate and variability of inflation. Inflation, and particularly erratic inflation, "jams" the signalling effects of relative prices (Friedman, 1977). This directly harms the process of allocating resources to their most highly valued uses, and therefore negatively impacts TFP. Moreover, erratic inflation makes it more risky to undertake long-term projects, and therefore may harm the incentives of those individuals who receive the residual income from such projects, that is, entrepreneurs (Knight, 1921). Finally, the concept and measurement of sound money is associated with the level of financial development and financial depth, and is as such a proxy for the access to capital.

Following Ventura (1997) we argue that the degree of openness to international trade and investment positively impacts the elasticity of substitution, and, in turn, TFP. Larger trade flows through a country may arguably imply more access to international price signals, thus allowing domestic agents to take advantage of not only national but also international opportunities. In addition, freedom to invest could, as is often found in empirical studies, increase the rate of technology adoption (cf. Wacziarg, 2001). The fewer restrictions on capital movements across borders, the easier the access to international capital markets. This increases the supply of venture capital, which may boost innovation (Cagetti and De Nardi, 2006; Kortum and Lerner, 2000).

Following Kirzner (1985) public regulation is an important item in an economic freedom measure that is relevant to understanding the flexibility with which the market system works and therefore also how TFP develops. Arguably, regulations can both help and hinder entrepreneurs who need clear rules and predictable enforcement of those rules. On the other hand, excessive regulations impose burdens on all firms, not the least start-ups, that may imply prohibitive start-up costs. In addition, Baumol (1990) made the point that individuals operating in heavily regulated economic environment may have larger gains from engaging in rent-seeking activities within the public sector — what he termed "destructive entrepreneurship" — than in real economic activities.

There are many reasons why the size of government may be expected on a priori grounds to influence TFP. Most directly, if economic activities in certain industries or sectors have essentially been nationalized, the scope for entrepreneurship in those industries and sections is reduced, as nationalization often (but of course not necessarily) implies a public monopoly. In most parts of the Western industrialized world this is clearly the case of child care, health care, and care of the elderly. The effective nationalization of these industries means that the operation of the price mechanism becomes severely hampered (Mises, 1949), eliminating entrepreneurship and reducing the adaptability of the industries to effectively adapt to changing circumstances.

As Henrekson (2005: 11) and Bjørnskov and Foss (2008) argue, to the extent that a large government is associated with high levels of publicly financed provision of various services (e.g., 
care of the elderly, education, etc.), with generous social security systems, and with levels of taxation, the incentives to engage in entrepreneurial acts in order to make a living (what is often called "necessity entrepreneurship") are reduced because a relatively high reservation wage is practically guaranteed and because entrepreneurial incomes are heavily taxed. Such schemes also reduce incentives for individual wealth formation which may be expected to negatively influence the level of entrepreneurial activity (Henrekson, 2005: 11). One reason has to do with entrepreneurial judgment being idiosyncratic and often hard to clearly communicate to potential investors (Knight, 1921). The entrepreneur may have to finance his venture himself, at least in the start-up phase. If individual wealth formation is reduced because of generous public transfer schemes, etc., this makes such financing difficult. Moreover, if entrepreneurs are only able to commit small amounts of personal capital to their entrepreneurial venture, their signal to potential outside investors concerning their commitment to the venture is correspondingly weaker.

However, some scholars have argued that large welfare states create the sufficient stability to allow more people to commit larger amounts of capital to entrepreneurial activities (Galbraith, 2006). ${ }^{4}$ Another mechanism introduced by Hirschman (1958) in connection with this ideas of "balanced growth" is the notion of a creative tension between government interventions and innovation: If government controls a large share of the economy, it places an artificial competitive pressure on private actors, which induces them to search for more productive solutions; that is, it forces them into entrepreneurial activities. In addition, we note that a positive association between government intervention and the marginal returns to entrepreneurship could arise as government activity pushes some entrepreneurs out of society, only leaving the most promising entrepreneurial ideas.

In sum, the above suggests the hypotheses that secure property rights, a high quality of regulations and the judicial system, sound money, openness to international trade and investment positively influence TFP, while a high level of regulation and a large government and high taxes may or may not be harmful to TFP.

A final issue concerns the possible interaction between entrepreneurship and institutions with respect to influencing TFP, and in particular how the institutional environment moderates the relationship between entrepreneurship and TFP. To a certain extent this has already been touched upon in the above discussion of the transmission mechanisms from entrepreneurship and institutions to influencing TFP: If the institutions of liberty that are captured by "freedom variables" positively impact TFP because they reduce uncertainty, increase predictability, and reduce transaction costs,

\footnotetext{
${ }^{4}$ We nevertheless note that the evidence for this argument is scant, and the available studies tend to show the exact opposite association between government size and entrepreneurial activity (Bjørnskov and Foss, 2008; Nyström, 2009).
} 
they largely do so because they pave the way for the kind of entrepreneurial experimentation that lead to productivity enhancing innovations in products, processes and ways of organizing productive activities. This reasoning therefore suggests the hypothesis that freedom variables positively impact the relation between entrepreneurship and TFP, in other words, the more economic freedom, the more strongly entrepreneurship will impact on overall productivity.

However, this same reasoning also implies that entrepreneurship at the margin could be more effective in countries with less economic freedom. Given that poor institutions and limited economic freedom also limits TFP and reduces the incentives for entrepreneurship (cf. Nyström, 2009; Méon and Weill, in press), the entrepreneurial activity actually observed in such countries is likely to be highly productive. As such, the medium-run interacting relationship between economic freedom and entrepreneurship (total or marginal) may be ambiguous.

\section{DATA, MEASURES, AND MODEL}

\section{Total Factor Productivity}

Like entrepreneurial activity, TFP cannot be measured with a high degree of precision. We follow a growing literature by calculating the so-called Solow-residual from growth accounting exercises. ${ }^{5}$ The basis for this approach is that development accounting decomposes the observed differences in levels of output per worker across countries into differences in the employment of input factors and a residual, which is taken to be international differences in TFP. The identifying assumption in such exercises is that production is characterized by the following Cobb-Douglas production function, which we outline in logs:

$$
\log Y=\log A+\alpha \log K+(1-\alpha) \log (L h)
$$

As usual, $Y$ is output, $K$ aggregate capital stock, $L$ the number of workers or work hours, and $h$ is the average stock of human capital; $L h$ thus measures the size of the quality-adjusted labor force. Furthermore, $\alpha$ measures the capital share of output while 1- $\alpha$ therefore measures the share contributed by quality-adjusted labor. The share of output that is not explained by input factors, that is $A$, logically must be TFP. ${ }^{6}$

This approach necessitates that one has a measure of the size of the stock of physical capital, $K$. While this stock is not measured directly, we follow standard practice in most papers by

\footnotetext{
${ }^{5}$ This and alternative approaches are surveyed in Caselli (2005). This paper also contains much information on the intricacies of estimating TFP.

${ }^{6}$ Note that although using a Cobb-Douglas function with the above restriction on the income share of capital and effective labor may seem restrictive, recent work by Aiyar and Dalgaard (2009) suggests that the loss of precision imposed by this specific functional form is minimal.
} 
estimating it using the perpetual inventory method (as in, e.g., King and Levine, 1994). Noting that the capital stock develops as $K_{t}=K_{t-1} \times(1-\delta)+I_{t-1}$, we set the depreciation rate to .06 . Investment rates are available from the Penn World Tables dataset since 1950 for most countries (Heston et al., 2006). This leaves the problem of how to assess the size of the initial capital stock, for which a reasonable guess is derived from the Solow-Swan growth model. Here, the initial stock of physical capital is given by $K_{0}=I_{0} /(g+\delta)$, where $I_{0}$ is the value of investment in the first year for which an observation is available, and $g$ is the average rate of growth for the following twenty years. As we use no data before 1980, the share of the initial capital stock still in use at any time during our period is likely to be small, which makes the consequences of assumptions surrounding the initial stock negligible. $^{7}$

With respect to measuring human capital, we follow Hall and Jones (1999) in estimating this as a piecewise linear function. ${ }^{8}$ We use data on the average length of schooling of individuals above the age of 25 from the widely used Barro-Lee dataset (Barro and Lee, 2001). As the final assumption, we need to make an assumption on the size of $\alpha$. Although this parameter is critical in development accounting exercises, the literature disagrees on which value is most consistent with real-world production functions (Caselli, 2005). We follow Bjørnskov and Méon's (2010) estimates and set $\alpha$ at .4 .

\section{Measuring Entrepreneurship}

With respect to measuring entrepreneurship, we use the dataset provided by the Compendia research group (van Stel, 2005). As raw data on self-employment in the OECD statistics are generally not comparable across countries, mainly due to variations in how owners/managers of incorporated businesses are included (OECD, 2009), data have to be harmonized before crosscountry comparisons make sense. The Compendia database addresses this problem by including owners/managers of both unincorporated and incorporated businesses. The data excludes unpaid family members working for the business, as well as people with self-employment as a secondary activity (van Steel, 2005). While this may lead to underestimating the full impact of entrepreneurship as the entrepreneurial associated with established firms is excluded, focusing solely on primary self-

\footnotetext{
${ }^{7}$ Given our assumption of an annual depreciation rate of $6 \%$ and the fact that the investment series in the Penn World Tables for most of our countries start in 1950, the maximum initial capital stock left in at the beginning of the period (1980) is $15 \%$ and only $3 \%$ at the end (2005). This makes the assumptions behind the construction of initial capital stocks rather innocuous.

${ }^{8}$ The specific form of $\phi$, the piecewise linear function, is $\phi(s)=0.134 \times s$ if $s \leq 4, \phi(s)=0.134 \times 4+0.101 \times(s-4)$ if $4<s \leq 8$, and $\phi(s)=0.134 \times 4+0.101 \times 4+0.068 \times(s-8)$ if $s>8$.
} 
employment ensures that we measure actual economic activity (Nyström 2009). ${ }^{9}$ By adding a control variable measuring the size of the population employed in agriculture, we implicitly assume that entrepreneurship is mainly associated with productivity improvements in the manufacture and service sectors. This control is also necessary as the Compendia data effectively excludes agricultural self-employment.

\section{Institutions}

Our institutional data all derive from the annual reports of the Fraser Institute on Economic Freedom in the World (Gwartney \& Lawson, 2009). These data have been used in many studies on growth and other macroeconomic outcomes (de Haan and Sturn, 2000; Méon and Weill, 2005; de Haan et al., 2006; Dreher et al., 2007; Knack and Heckelman, 2007; Aghion, Algan, Cahuc and Shleifer., 2008; Bjørnskov, 2008; Justesen, 2008), and are usually deemed to be among the most precise institutional measures available (Berggren, 2003).

Rather than using the full index of economic freedom, we employ the five sub-indices of economic freedom. These indices are meant to cover five distinct areas of institutions and overarching policies, the first of which is Government size. This index measures the extent to which the government intervenes in the economy through consumption, redistribution through transfer schemes, public investments, and marginal taxation. In separate analyses, we alternatively split it into its four sub-components. Government consumption is measured as the share of general government consumption spending in total consumption; transfers and subsidies as general government transfers and subsidies as a share of GDP; government enterprises and investment is measured as the share of output supplied by state-operated enterprises and government investment as a share of total investment; and the tax burden index is an index composed of the top marginal income and payroll tax rates and the share of income threshold at which they take effect (Gwartney and Lawson, 2009).

The second measure of institutional and policy quality is that of Legal quality, measuring the protection and respect for the rights of people to their own lives and rightfully acquired property. The legal quality index is composed of indicators of judicial independence, impartiality of the courts, protection of intellectual property rights, military interference in law and politics, and integrity of the legal system. A third index captures Sound money, defined as the rate and variability of inflation and monetary controls. As such, this is a measure of the consistency of monetary policy but also captures notions of financial sector development and financial depth. Fourth, the economic freedom data

\footnotetext{
${ }^{9}$ Previous papers have employed the data provided by the Global Entrepreneurship consortium (e.g. Levie and Auttio, 2008; Bjørnskov and Foss, 2008). However, these data only allow estimating a consistent panel between 2001 and 2006 , which does not provide sufficient variation to estimate the full effects of institutions (see also OECD, 2009).
} 
includes an index of Freedom to trade internationally, which measures the extent of trade and barriers to trade and capital flows through actual trade and investment flows and through indicators of tariff and non-tariff barriers to trade and capital. Finally, the data include an index of Regulatory quality, composed of three sub-indices of the freedom from government regulations and controls in the labour market, financial and credit markets, and the price controls in the markets for goods and services. These three areas are again composed of: 1) the impact of minimum wages, hiring and firing practices, the share of the labour force with wages set in centralized bargaining, the generosity of unemployment benefits, and the use of conscript military personnel; 2) the percentage of deposits held in privately owned banks, bank competition, percentage of credit extended to the private sector, and the extent of interest rate controls; and 3) price controls, administrative procedures that are obstacles to business, time spent with the bureaucracy, the ease of starting new businesses, and the necessity of irregular payments.

\section{Control Variables}

We also add a set of other determinants of TFP that seem to be emerging as standard controls in the literature. The array of additional control variables includes openness, measured as trade volumes as percent of GDP, government final consumption (i.e. government consumption excluding transfers), a dummy for post-communist countries, the share of the population employed in agriculture, and a full set of period dummies to take jointly international productivity increases into account. The former variables derive from the Penn World Tables, mark 6.2 (Heston et al., 2006), while agricultural employment is from the World Bank (2009) database.

We employ two further variables as instruments. The first is the price level of capital and investment goods from the Penn World Tables. The second is Dreher's (2006) measure of information flows, which captures the size and ease of information flows to a country from the rest of the world. We provide test statistics for these instruments throughout; note that their inclusion also means that any interaction is instrumented as well. All data are summarized in Table 1.

\section{Insert Table 1 here}

\section{Specification and Estimation Strategy}

These data give us a slightly unbalanced panel of 25 countries observed in the six five-year intervals between 1980 and 2005 . $^{10}$ The countries and their 2005 levels of TFP relative to the US are

\footnotetext{
${ }^{10}$ Although this may give rise to an issue with unobserved heterogeneity, we submit that this is not likely to be a major problem as only 10 out of 150 potential observations are missing.
} 
listed in the appendix. In the following, we estimate the determinants of TFP through the simple specification in (2), where $\mathrm{A}$ is TFP, $\mathrm{E}$ is entrepreneurial activity, $\mathrm{F}$ is a vector of the economic freedom variables, $\mathrm{X}$ is a vector of control variables, $\mathrm{a}, \mathrm{b}, \mathrm{c}, \mathrm{d}$ are the coefficients to be estimated, and $\mathrm{u}$ is a normally distributed error term. In a further set of regressions, we also include interaction terms between $\mathrm{E}$ and $\mathrm{F}$ in order to test the hypothesis that that the effects of entrepreneurship are moderated by the institutional environment.

$$
A=a+b E+c F+d X+u
$$

We first present our main results estimated by simple OLS with Beck and Katz's (1995) panelcorrected standard errors, which we subsequently supplement in two different ways. ${ }^{11}$ To alleviate the problem of endogeneity and simultaneity, we first shift to providing instrumental variables estimates. This is necessary, as potential entrepreneurs might rationally react to opportunities resulting from being behind the international production possibility frontier, so that TPF drives entrepreneurship. Specifically, it is arguable that lacking productivity may induce higher levels of entrepreneurship, given that being far from the production possibility frontier may imply higher potential returns to entrepreneurial activity. As tests suggest that this is a problem, simple OLS will be biased, and we therefore instrument for entrepreneurship in a set of two-stage least squares estimates.

Second, our theoretical considerations suggest that the effects of entrepreneurship might be heterogeneous across economic policies and institutions. We therefore provide a set of estimates including interaction terms. We outline the conditional effects of entrepreneurship, bearing in mind that such estimates must be interpreted with care, as both effects and standard errors are conditional (cf. Brambor, Clark and Golder, 2006).

We note that the TFP measures themselves are estimates. Even if the literature on TFP ignores this problem and employs these estimates as if they were precise, we acknowledge this problem and therefore also provide a set of results with bootstrapped standard errors.

\section{RESULTS}

\section{Basic Results}

We report the results of estimating the effects of economic freedom and entrepreneurship on TFP in Table 2 below. Columns 1 and 2 provide the baseline, estimated by simple OLS. We first note that our control variables turn out as expected. Government final consumption, measuring the

\footnotetext{
${ }^{11}$ Ideally, one would estimate these relations using a more "proper" panel data estimator. However, when having only six periods in an unbalanced panel of 25 countries, standard random and fixed effects GLS estimators are inefficient. We therefore rely on simpler techniques, supplemented by robustness tests.
} 
extent to which productive economic activity takes place in the public sector, is strongly negatively associated with TFP; openness to trade is positively associated; while the share of the population employed in agriculture is negatively associated with TFP. However, the status of post-communist countries is unclear, although they remain less productive than other OECD countries. Yet, we note that both Hungarian and Polish TFP have converged rapidly towards OECD standards in recent years. Finally, the five-year period dummies (not shown) exhibit a clear, joint international trend towards higher TFP.

Insert Table 2 here

Turning to our central variables in column 1, only one of the five indices of economic freedom turns out to be statistically significant. Government size-which is composed of indices capturing the extent to which government intervenes in the economy through consumption, redistribution through transfer schemes, public investments, and marginal taxation-is negatively associated with TFP. As the index measures the freedom from government intervention, it suggests that more intervention is associated with higher TFP. However, we note that since we have already controlled for the size of production in the government sector, what we effectively find is that government intervention affects the productivity of non-government production. The other central feature, our measure of entrepreneurship, is significantly positively associated with TFP. Column 2 shows that this association is not affected by deleting insignificant institutional variables. ${ }^{12}$

\section{Instrumenting Entrepreneurship}

However, OLS estimates are likely to suffer from endogeneity bias if entrepreneurs react to opportunities associated with, for example, being far from the production possibility frontier. In columns 3-5, we therefore instrument entrepreneurship, using two intuitive variables. We employ the price level of capital and investment goods, which derives from the Penn World Tables (Heston et al., 2006). This variable is a proxy for the costs of setting up a business, which would necessarily be negatively associated with actual entrepreneurial activity, as opposed to potential entrepreneurship. The second instrument is Dreher's (2006) measure of global information flows, which proxies for the ease with which new ideas and information reaches potential entrepreneurs. The partial R squared from a first stage regression with these instruments is .36. Relying on the estimates reported in

\footnotetext{
12 As entrepreneurship is associated with government size (cf. Nyström, 2009), any interaction effects may simply capture a non-linearity if the interaction term proxies for a squared entrepreneurship term. However, we have tested these association by adding a squared term. These tests show that the effect of entrepreneurship on its own is approximately linear. We can therefore have some confidence in the interpretation of the further results.
} 
column 3 is moreover strongly warranted, as a Durbin-Wu-Hausman test indicates that selfemployment is clearly endogenous (Chi squared $=13.977 ; \mathrm{p}<.000$ ).

The IV estimates of entrepreneurship show a correspondingly larger effect, which we-given that the instruments pass tests for over- and underidentification-can interpret causally. In other words, we find evidence for a strong effect of entrepreneurship on TFP, which approximately doubles when we deal with what appears to be strong endogeneity bias.

\section{Entrepreneurship and Government Size}

The estimates in columns 4 and 5 in which we add an interaction term between government size and entrepreneurship (the latter excludes clear outliers) suggest that this effect is heterogeneous in elements of economic policy. The more governments intervene (i.e., the lower the government size index), the smaller the effect of entrepreneurship. This association is illustrated in Figure 1, which includes the conditional confidence intervals. As can be seen in the figure, the relation becomes insignificant at levels above approximately 8.5 , that is, a very high level. We do not show interactions with the remaining four indices of economic freedom, as none were significant.

\section{Insert Figure 1 here}

We explore these results further in Table 4 in which we attempt to tease out which elements of government size are responsible for the effects. Before doing so, we nevertheless need to ascertain that the four subindices, from which the overall government index are constructed, are likely to measure different aspects of economic policy. This index has been the subject of prolonged debate in the literature with the assertion that it measures several aspects that are only weakly associated with each other (e.g., de Haan et al., 2006). The simple correlations reported in Table 3 also suggest that the four subindices are sufficiently differentiated to allow estimation of different effects. We therefore enter each of the four subindices and their interaction with entrepreneurship sequentially in Table 4; column 1 replicates the results in Table 2, column 4.

Insert Table 3 here

Insert Table 4 here

The results of two indices - that is, government enterprises and investment, and the tax burden as captured by the size and extent of the top marginal tax-both have interactions with 
entrepreneurship that are significant across most of their distribution. Both interactions with government enterprises and the tax burden are negative, suggesting that entrepreneurship is relatively more important in societies in which the government plays a dominant role in the economy, either through production in government-owned enterprises and investments or in its financing activities. Neither government consumption, nor transfers and subsidies seem to significantly moderate the influence of entrepreneurship.

Even though the subindices are sufficiently correlated to be separable, the interaction terms are highly correlated by construction. Some multicollinearity is thus unavoidable when including more than one of these terms. To be able to separate effects, we therefore performed a "beauty contest" in which we included all combinations of two subindices and their interaction terms with entrepreneurship. ${ }^{13}$ The outcome of this contest can be summarized as follows. Including interactions with the transfers and subsidies index does not significantly alter any other results, although the index per se is often negatively significant. Including the government enterprises index along with the tax burden reduces the interaction effect of the tax burden index, although it stays significant across most of its distribution. Given the significant correlation between these indices (crosssectional as well as time-series), one must nevertheless be cautious in drawing the conclusion that the tax burden is the less important index. Both these findings are robust to including the remaining two indices and their interactions.

A careful reading of the beauty contest suggests that the influence of the level of entrepreneurial activity on TFP is mediated by the extent to which the government participates in actual productive activities (the government enterprises index) and by level and progressivity of the tax system. To illustrate these findings, Figures $2 \mathrm{a}$ and $2 \mathrm{~b}$ plot the association between entrepreneurship and TFP, conditional on the level of each subindex of government size.

To make further sure that our conclusions are robust, we perform two types of robustness tests. We first perform a jackknife exercise in which we test the robustness of the main results in Table 4 by excluding one country at a time from the sample. We then bootstrap our standard errors. The results of the jackknife exercise are reported in Table 5.

\section{Insert Table 5 here}

\footnotetext{
${ }^{13}$ Due to the intricacies associated with evaluating interaction effects (Brambor et al., 2006), we do not report the specifics of the beauty contest. The standard test statistics such as coefficients and standard errors or t-statistics assessed at the sample mean do not hold sufficient relevant information for testing interactions against each other.
} 
The results suggest that at least one of the findings is relatively robust to excluding single countries, and therefore not likely to be driven by outliers. For both government enterprises and the tax burden, the exclusion of Mexico results in the smallest estimate of entrepreneurship, as evaluated at the sample mean of government size, and the exclusion of Australia results in the largest estimate. The bootstrapped standard errors also change very little.

Yet, while the simple test statistics do not indicate any change in effects of entrepreneurship at the mean level, excluding Mexico leaves the interaction of the tax burden insignificant across its entire distribution. However, excluding either Mexico or Australia, that is, the two observations with the largest statistical leverage, restores the result. For the government enterprise index, we find that the size of the interaction effect is sensitive to leaving out these two countries, but remains significant throughout. We consequently must conclude that this particular result is robust, while the robustness of the tax burden result is debatable.

Finally, to illustrate the quantitative importance of entrepreneurship at different levels of government intervention in the economy, Table 6 provides the point estimates at the sample mean and the $25^{\text {th }}$ and $75^{\text {th }}$ percentiles of the distributions of the indices of government enterprises and tax burden, respectively. The figure in italics can be interpreted as the long-run impact of permanently increasing entrepreneurial activity by one standard deviation, or approximately six percentage points.

\section{Insert Table 6 here}

Increasing entrepreneurial activity in the typical country in our sample induces a long-run change in TFP of roughly $85 \%$ of a standard deviation in our average country. At the average level of active government involvement in the economy (the government enterprises index), this is reduced to $54 \%$ (due to the highly skewed distribution of this index) and $88 \%$ of a standard deviation at the average tax burden, that is, at the average financing structure of the government sector. However, increasing governments' active involvement to the $25^{\text {th }}$ percentile, about the level of France, increases the impact to $71 \%$. Correspondingly, increasing the tax burden to the $25^{\text {th }}$ percentile, which is roughly the average European level, increases the marginal efficiency of entrepreneurial activity to $103 \%$.

\section{CONCLUDING DISCUSSION}

Emerging literatures in the economics of growth examine the contribution of institutions and entrepreneurship to the explanation of the growth process. However, few papers consider both determinants simultaneously - the main purpose of this paper- perhaps due to the intricacies 
involved in featuring institutions and entrepreneurship in the same model, as well as the general problem of securing reliable data on entrepreneurship. There is, however, a need to bring these determinants together, as there are strong reasons to suspect that they are closely intertwined in the growth process. Specifically, although we cannot directly test these ideas based on the aggregate data in our panel, we have argued that entrepreneurship influences total factor productivity because the optimum combination of productive factors is not a datum but needs to be discovered by enterprising firms and individuals. We argued that it is particularly natural to assume that entrepreneurship will impact TFP. Similarly, we argued that the effect of institutions on TFP is mediated through the reduction of uncertainty and transaction costs that institutions may bring about (cf. North, 1991). In turn, the link from entrepreneurship to total factor productivity is moderated by institutions and economic policy. Relative to the extant literature, our emphasis on TPF as well as the moderation effect of institutions are novel contributions.

Relying on harmonized entrepreneurship data (van Stel, 2005) we built a unique panel dataset consisting of 25 countries observed in the six five-year intervals between 1980 and 2005, and tested the influence of entrepreneurship and institutions on TFP as well as the moderation effect of institutions on the entrepreneurship-TFP link. While entrepreneurship strongly and significantly impacts TFP, our results only partially support the intuition that institutions of liberty as well as liberal economic policies promote growth in productivity. In fact, we find no significant effects of sound money and legal quality on TFP in the medium run. When some of the freedom variables are interacted with the entrepreneurship variable, we in fact find that entrepreneurial activity is more effective in raising levels of TFP in environments dominated or strongly influenced by government activity, either through production in government-owned enterprises and investments or in its financing activities. Thus, increasing the active involvement of the government in the economy as well as the tax burden actually increases the impact of entrepreneurship on TFP.

This runs counter to our initial theoretical expectation, and, at first glance, the finding seems surprising. The problem that the public sector does not directly innovate would seem to be a major problem with a large welfare state; however, our perhaps key finding in this paper is that entrepreneurship is in fact most effective in terms of raising productivity under exactly these conditions. From the perspective of proponents of a large welfare state apparatus, this might be good news, as the effectiveness of entrepreneurship in terms of impacting overall productivity limits, as it were, how bad the economy performs in a welfare state. Moreover, some may take our finding as evidence that the state can successfully raise the effectiveness of entrepreneurship in terms of increasing overall productivity. Thus, our results may suggest that investments in public “infrastructure services" (Barro, 1990) may positively impact productivity because they are 
complementary to (private) investments undertaken by entrepreneurs in the improvement of processes, products, organizations, etc. (cf. also Hirschman, 1958).

On the other hand, this may well be a too hasty conclusion, as the relation between entrepreneurship, TFP and the size of the welfare state is not trivial, and may perhaps best be thought of as a recursive system. While our results suggest that the effect of entrepreneurship on TFP is larger in welfare states, other work has found that the welfare state significantly reduces the supply of entrepreneurship (Henrekson, 2005; Kreft and Sobel, 2005; Bjørnskov and Foss, 2008; Nystrøm, 2009). The welfare state-entrepreneurship association must therefore instead be thought of as a system in which one element undermines the supply of the other, and thereby increases its measured effectiveness. As a consequence, it a priori seems quite reasonable to infer that a reduced supply of entrepreneurship increases the marginal productivity of entrepreneurship; thus, the best ideas do survive even in the relatively hostile welfare state environment (Henreksson, 2005). This is very likely the basic mechanism that explains our finding. Moreover, from the overall perspective of job creation, it is quite likely that it is desirable that not only the very best entrepreneurial ideas survive, but also the good, but not great ones. There is some evidence that a few major entrepreneurial ideas and firms may sometimes impact the performance of a whole economy - the telecommunications giant Nokia in Finland is often mentioned as an example - and of course major technological breakthroughs have decisively influenced growth and development in the course of economic history (cf. Mokyr, 2006). And yet, it is seldom the case that a few major entrepreneurial innovations have the potential to decisively influence so many sectors in the economy that they can drive overall job creation. It is in fact increasingly the case that job creation is driven by self-employment and small firms (Arzeni, 1998; Baptista, Escaria \& Madruga, 2007; Malchow-Møller, Schjerning \& Sørensen, 2009). A large welfare state represents numerous barriers to start-up activity (Henreksson, 2005; Bjørnskov \& Foss, 2008); overall job creation and employment levels suffer as a consequence (for evidence from the OECD, see Fonseca, Lopez-Garcia \& Pissarides, 2001). In this perspective, one can thus think of entrepreneurial ventures as activities that are limited by the rise of the welfare state, although they protect welfare states from falling too far behind in terms of productivity in the private sector that necessarily finances welfare spending. The long-run dynamics of such political-economic systems seem worthy of further research.

\section{APPENDIX}

Insert Table A1 here 


\section{REFERENCES}

Acemoglu, D. 1995. "Reward Structures and the Allocation of Talent," European Economic Review, 39: 17-33.

Acs, Z. J., P. Braunerhjelm, D. B. Audretsch, and B. Carlsson. 2009. "The Knowledge Spillover Theory of Entrepreneurship," Small Business Economics, 32: 15-30.

Aghion, P., Y. Algan, P. Cahuc and A. Shleifer. 2008. "Regulation and Distrust.” NBER Working Paper 14648.

Aghion, P. and Durlauf, S., eds. 2005. Handbook of Economic Growth, Oxford: Oxford University Press.

Aghion, P. and Howitt, P. 1998. "Capital Accumulation and Innovation is Complementary Factors in Long-Run Growth.” Journal of Economic Growth, 3, 111-130.

Aiyar, S. and C.-J. Dalgaard. 2009. "Accounting for productivity: Is it OK to assume that the world is Cobb-Douglas?" Journal of Macroeconomics, 31: 290-303.

Aquilina, M, R. Klump, and C. Pietrobelli. 2006. "Factor Substitution, Average Firm Size, and Economic Growth,” Small Business Economics, 26: 203-214.

Arrow, K., H.B. Chenery, B.S.Minhas, and R.M. Solow. 1961. "Capital-Labour Substitution and Economic Efficiency." Review of Economics and Statistics, 43: 225-250.

Arzeni, S. 1998. "Entrepreneurship and Job Creation," OECD Observer.

Audretsch, D. B., Carree, M. A., van Stel, A. J., and T. A. Roy 2003. "Impeded Industrial Restructuring: The Growth Penalty," Kyklos, 55: 81 - 98.

Baptista, R. V. Escária \& P Madruga. 2008. "Entrepreneurship, regional development and job creation: the case of Portugal," Small Business Economics, 30: 49-58.

Baumol, W. J. 1990. "Entrepreneurship: Productive, Unproductive, and Destructive," Journal of Political Economy 98: 893-919.

Baumol, W. J. 1993. Entrepreneurship, Management and the Structure of Payoffs. Cambridge, MA: MIT Press.

Barro, R.J. 1990. “Government Spending in a Simple Model of Endogeneous Growth,” Journal of Political Economy, 98: 103-125. 
Barro, R.J. 1991. "Economic Growth in a Cross-section of Countries," Quarterly Journal of Economics 106: 407-443.

Barro, R.J. and J-W. Lee. 2001. "International Data on Educational Attainment: Updates and Implications." Oxford Economic Papers 53, 541-563.

Barzel, Y. 2005. A Theory of the State. Cambridge: Cambridge University Press.

Baumol, W.J. 1993. Entrepreneurship, Management, and the Structure of Payoffs. Cambridge: MIT Press.

Baumol, W.J. 1996. "Entrepreneurship: Productive, Unproductive, and Destructive," Journal of Business Venturing, 11: 3-22.

Beck, N. and J.N. Katz. 1995. "Nuisance vs. substance: Specifying and Estimating Time-Series Cross Section Models." Political Analysis 6, 1-36.

Berggren, N. 2003. The Benefits of Economic Freedom: A Survey. Independent Review 8: 193-211.

Beugelsdijk, S., H. L.F. de Groot, and A. B.T.M. van Schaik. 2004. Trust and Economic Growth: A Robustness Analysis. Oxford Economic Papers 56, 118-134.

Bjørnskov, C. 2008. The growth-inequality association: Government ideology matters. Journal of Development Economics, vol. 87, 300-308.

Bjørnskov, C. and N. J. Foss. 2008. "Economic Freedom and Entrepreneurial Activity: Some CrossCountry Evidence." Public Choice, vol. 134, 307-328.

Bjørnskov, C. and P-G. Méon. 2010. "The Productivity of Trust” Mimeo, Université Libre de Bruxelles.

Brambor, T., W.R. Clark and M. Golder. 2006. "Understanding interaction models: Improving empirical analysis." Political Analysis 14: 63-82.

Cagetti, M. and DeNardi, M. 2006. "Entrepreneurship, Frictions, and Wealth," Journal of Political Economy, 114: 835-870.

Capelleras, J.-L.,Mole, K.F., Greene, F.J., and Storey, D.J. 2007. "Do More Heavily Regulated Economies Have Poorer Performing New Ventures? Evidence From Britain and Spain," Journal of International Business Studies, 37: 1-17.

Carlsson and Lundström. 2002. "Economic Freedom and Growth: Decomposing the Effects," Public Choice, 112: 335-344.

Caselli, F. 2005. Accounting for cross-country income differences. In: P. Aghion and S. Durlauf (Eds.), Handbook of Economic Growth, Elsevier, 679-742.

Coe, D.T. and E. Helpman. 1995. "International R\&D Spillovers,” European Economic Review, 39: 859-887.

Demsetz, H. 1967. “Toward a Theory of Property Rights," American Economic Review, 57: 347-359. 
Dreher, A. 2006. "Does Globalization Affect Growth? Evidence From a New Index of Globalization." Applied Economics 38, 1091-110.

Dreher, A., C. Kotsogiannis and S. McCorriston. 2007. "Corruption around the World: Evidence from a Structural Model”. Journal of Comparative Economics 35, 443-466.

Erken, H., P. Donselaar, and R. Thurik. 2008. "Total Factor Productivity and the Role of Entrepreneurship.” Jena Economic Research Papers 2008-019.

Fagerberg, J.. 1987. “A Technology Gap Approach to Why Growth Rates Differ,” Research Policy, 16: 87-99.

Fonseca, R. P. Lopez-Garcia and C. A. Pissarides. 2001. "Entrepreneurship, Start-up Costs and Employment," European Economic Review, 45: 692-705.

Foss, K., Foss, N. Klein P.G. and Klein. S. 2007. "Heterogenous Capital and the Organization of Entrepreneurship,” Journal of Management Studies 44: 1165-1186.

Foster, L., Haltiwanger, J. C., and C. J. Krizan 2002. "The Link Between Aggregate and Micro Productivity Growth: Evidence From Retail Trade.” NBER Working Paper Series (9120).

Friedman, M. 1962. Capitalism and Freedom. Chicago: University of Chicago Press.

Friedman, M. 1977."Nobel Lecture: Inflation and Unemployment”. Journal of Political Economy, 85: 451-472.

Glaeser, E., La Porta, R., Lopez de Silanes, F., Shleifer, A. 2004. "Do Institutions Cause Growth?” Journal of Economic Growth 9: 271-303.

Gwartney, J., Lawson, R. 2009. Economic Freedom of the World: 2097 Annual Report. Vancouver: Fraser Institute.

Gwartney, J., Lawson, R. Holcombe, R. 1999. "Economic freedom and the environment for economic growth." Journal of Institutional and Theoretical Economics 155: 643-663.

De Haan, J., S. Lundström and J.-E. Sturm, 2006. "Market-oriented Institutions and Policies and economic Growth: a Critical Survey," Journal of Economic Surveys 20: 157-191.

Haan, J de. And J.-E. Sturm. 2000. "On the relationship between economic freedom and economic growth.” European Journal of Political Economy 16: 215-241.

Hall, R.E. and C.I. Jones. 1999. "Why Do Some Countries Produce So Much More Output Per Worker Than Others?," The Quarterly Journal of Economics, 114: 83-116.

Hall, J. and R. Sobel. 2008. "Institutions, Entrepreneurship, and Regional Differences in Economic Growth" Southern Journal of Entrepreneurship, 1: 69-96.

Hayek, F.A. 1945. "The Use of Knowledge in Society," in idem. 1948. Individualism and Economic Order. Chicago: Chicago University Press. 
Hayek, F.A. 1968. "Competition as a Discovery Procedure." Translated by Marcellus S. Snow. Quarterly Journal of Austrian Economics 5 (3): 9-23 (2002).

Hayek, F.A. 1973. Law, Legislation, and Liberty, Vol. 1: Rules and Order. Chicago: University of Chicago Press.

Henrekson, M. 2005. "Entrepreneurship: a Weak Link in the Welfare state?" Industrial and Corporate Change, 14: 437-467.

Heston, A., Summers, R., and B. Aten. 2006. Penn World Tables Version 6.2. University of Pennsylvania: Center for International Comparisons of Production, Income and Prices.

Hirschman, A. O. 1958. The Strategy of Economic Development. New Haven, CT: Yale University Press.

Holcombe, R. 1998. "Entrepreneurship and Economic Growth.” Quarterly Journal of Austrian Economics 1: 45-62.

Hulten, C.R. 2001. "Total Factor Productivity: A Short Biography," in New Developments in Productivity Analysis, eds. C.R. Hulten, E.R. Dean and M.J. Harper. Boston: NBER Books.

Jones, C. I, 1995. "R\&D-Based Models of Economic Growth,” Journal of Political Economy, 103: 759-784.

Justesen, M.K. 2008. "The Effect of Economic Freedom on Growth: New Evidence From a Panel of Countries, 1970-1999." European Journal of Political Economy 24, 642-660.

Kirzner, I.M. 1980. "The Prime Mover of Progress". In Kirzner, I., Seldon, A. (Eds.) The entrepreneur in capitalism and socialism. London: Institute of Economic Affairs.

Kirzner, I.M. 1985. Discovery and the Capitalist Process. Chicago: University of Chicago Press.

Kirzner, I.M. 1997. "Entrepreneurial Discovery and the Competitive Market Process: an Austrian Approach." Journal of Economic Literature 35: 60-85.

Klein, P.G. and Luu, H. 2003. "Politics and Productivity." Economic Inquiry, 41, 433-447.

Klenow, P.J., and Rodriguez-Clare, A. 1997. "The Neoclassical Revival in Growth Economics: Has It Gone Too Far?,” NBER Macroeconomics Annual, 12: 73-103.

Klump, R., and Grandville, O. de la. 2000. "Economic Growth and the Elasticity of Substitution: Two Theorems and Some Suggestions," American Economic Review 90, 282-291.

Knack, S., and Heckelman, J. 2007. "Foreign Aid and Market-liberalizing Reform.” Economica 75, 524-548.

Knack, S. and P. Keefer. 1995. "Institutions and Economic Performance: Cross-Country Tests Using Alternative Institutional Measures.” Economics and Politics, 7: 207-227.

Knight, F.H. 1921. Risk, Uncertainty, and Profit. New York: Augustus M. Lelley. 
Kortum, S., and J. Lerner, 2000. "Assessing the Contribution of Venture Capital to Innovation." Rand Journal of Economics 31: 674-691.

Kreft, S.F. and R.S. Sobel. 2005. "Public policy, Entrepreneurship, and Economic Freedom.” Cato Journal 25, 595-616.

Lachmann, L. M. 1956. Capital and Its Structure. Kansas City: Sheed Andrews and McMeel, 1978.

Levie, J. and E. Autio. 2008. "A Theoretical Grounding and Test of the GEM Model," Small Business Economics, 31: 235-263.

Lucas, R. 1988. "On the Mechanics of Economic Development” Journal of Monetary Economics 22, $3-42$.

McGuinness, A. 2007. "Institutions and Total Factor Productivity Convergence," Working Paper, Central Bank and Financial Services Authority of Ireland.

Madsen, J.B. 2008. "Economic Growth, TFP Convergence, and the World Export of Ideas: A Century of Evidence". Scandinavian Journal of Economics, 110, 145-167.

Malchow-Møller, N., B. Schjerning and A Sørensen. 2009. "Entrepreneurship, Job Creation, and Wage Growth," No 2009-01, CAM Working Papers, University of Copenhagen. Department of Economics. Centre for Applied Microeconometrics

Matsusaka, J. 2001. "Corporate Diversification, Value Maximization, and Organizational Capabilities" Journal of Business, 74: 409-432.

Mauro, P. 1995. “Corruption and Growth.” Quarterly Journal of Economics, 110: 681-712.

Méon, P.-G. and L. Weill. 2005. "Does Better Governance Foster Efficiency? An Aggregate Frontier Analysis." Economics of Governance 6: 75-90.

Mises, L.v. 1949. Human Action: A Treatise on Economics. London: William Hodge.

Miyagiwa, K. and Papageorgiou, C. 2007. "Endogenous Aggregate Elasticity of Substitution." Journal of Economic Dynamics and Control, 31: 2899-2919.

Mokyr, J. 2006. "Long-term Economic Growth and the History of Technology.” In P. Aghion and S. Durlauf, Eds. Handbook of economic growth, Oxford: Oxford University Press.

Nicoletti, G., S. Scarpetta, and P. R. Lane. 2003. "Regulation, Productivity and Growth: OECD Evidence." Economic Policy 18, 11-72.

Nyström, K. 2009. "The Institutions of Economic Freedom and Entrepreneurship: Evidence From Panel Data." Public Choice, 136, 269-282. 
North, D. N. 1990. Institutions, Institutional Change, and Economic Performance. Cambridge: Cambridge University Press.

Nyström, K. 2009. “The Institutions of Economic Freedom and Entrepreneurship: Evidence From Panel Data," Public Choice, 136: 269-282.

OECD (Eurostat Entrepreneurship Indicators Programme). 2009. Measuring Entrepreneurship. Paris: OECD.

Olson, M. 1982. The Rise and Decline of Nations: Economic Growth, Stagflation, and Social Rigidities. Yale University Press.

Olson, M. 1996. "Big Bills Left on the Sidewalk; Why Some Nations Are Rich, Others Poor," Journal of Economic Perspectives, 10: 3-24.

Rodrik' D., Subramanian, A. and Trebbi, F. 2004. “Institutions Rule: The Primacy of Institutions Over Geography and Integration in Economic Development," Journal of Economic Growth, 9:131-165.

Romer, P. 1990. “Endogenous Technological Change.” Journal of Political Economy 98, 71-102.

Rosenberg, N. 1992. “Economic Experiments,” Industrial and Corporate Change 1, 181-203.

Schumpeter, J. A. 1939. Business Cycles: A Theoretical, Historical and Statistical Analysis of the Capitalist Process. New York: McGraw-Hill.

Solow, R. 1956. “A Contribution to the Theory of Growth," Quarterly Journal of Economics, 70: 6594.

Solow, R. 1957. "Technical Change and the Aggregate Production Function," The Review of Economics and Statistics, 39: 312-320.

Sturm, J-E., Leertouwer, E., de Haan, J. 2002. "Which economic freedoms contribute to growth? A Comment". Kyklos 55, 403-416.

Tabellini, G. 2008. "The Scope of Cooperation: Values and Incentives. Quarterly Journal of Economics, 123, 905-950.

Temple, J. 1999. “The New Growth Evidence.” Journal of Economic Literature, 37: 112-156.

van Stel, A. J. 2005. “COMPENDIA: Harmonising Business Ownership Data Across Countries and Over Iime." International Entrepreneurship and Management Journal 1, 105-123.

Ventura, J. 1997. “Growth and Interdependence.” Quarterly Journal of Economics, 62: 57-84.

Wazciarg, R. 2001. "Measuring the Dynamic Gains From Trade.” World Bank Economic Review 15, 393-429.

World Bank. 2009. World Development Indicators. Washington, DC: The World Bank. 
Table 1. Descriptive statistics

\begin{tabular}{lccc}
\hline Variable & Mean & Standard deviation & Observations \\
\hline Agricultural employment & 3.80572 & 2.7413 & 140 \\
Government consumption & 4.784 & 1.650 & 140 \\
Government enterprise & 6.807 & 2.487 & 140 \\
Government final consumption & 15.043 & 3.882 & 140 \\
Government size & 4.864 & 1.268 & 140 \\
Information flows & 75.318 & 17.318 & 140 \\
Investment prices & 82.857 & 23.410 & 140 \\
Legal quality & 7.917 & 1.068 & 140 \\
Log population size & 9.609 & 1.469 & 140 \\
Openness & 68.746 & 32.439 & 140 \\
Postcommunist & .050 & .219 & 140 \\
Self employment & 14.988 & 5.816 & 140 \\
Sound money & 8.507 & 1.627 & 140 \\
Special production & .086 & .289 & 139 \\
Tax burden & 2.856 & 2.226 & 140 \\
Total factor productivity & 87.858 & 12.254 & 140 \\
Transfers and subsidies & 5.012 & 1.694 & 1.02 \\
Regulatory freedom & 6.357 & & \\
\hline
\end{tabular}


Table 2. Basic estimates, determinants of total factor productivity

\begin{tabular}{|c|c|c|c|c|c|}
\hline & $\begin{array}{c}1 \\
\text { OLS }\end{array}$ & $\begin{array}{c}2 \\
\text { OLS }\end{array}$ & $\begin{array}{c}3 \\
2 S L S\end{array}$ & $\begin{array}{c}4 \\
2 \mathrm{SLS}\end{array}$ & $\begin{array}{c}5 \\
2 S L S\end{array}$ \\
\hline $\begin{array}{l}\text { Government final } \\
\text { consumption }\end{array}$ & $\begin{array}{c}-1.014 * * * \\
(.267)\end{array}$ & $\begin{array}{c}-1.169^{* * *} \\
(.247)\end{array}$ & $\begin{array}{c}-1.114 * * * \\
(.243)\end{array}$ & $\begin{array}{c}-.998 * * * \\
(.318)\end{array}$ & $\begin{array}{c}-1.136^{* * *} \\
(.290)\end{array}$ \\
\hline Openness & $\begin{array}{l}.071 * * * \\
(.026)\end{array}$ & $\begin{array}{c}.072 * * * \\
(.026)\end{array}$ & $\begin{array}{c}.081 * * * \\
(.027)\end{array}$ & $\begin{array}{l}.073 * * \\
(.030)\end{array}$ & $\begin{array}{l}.074 * * \\
(.029)\end{array}$ \\
\hline $\begin{array}{l}\text { Agricultural } \\
\text { employment }\end{array}$ & $\begin{array}{c}-3.785^{* * *} \\
(.488)\end{array}$ & $\begin{array}{c}-3.379 * * * \\
(.439)\end{array}$ & $\begin{array}{c}-5.078^{* * *} \\
(.645)\end{array}$ & $\begin{array}{c}-5.156^{* * * *} \\
(.641)\end{array}$ & $\begin{array}{c}-5.481 * * * \\
(.651)\end{array}$ \\
\hline Government size & $\begin{array}{c}-1.742 * \\
(.919)\end{array}$ & $\begin{array}{c}-2.957 * * * \\
(.711)\end{array}$ & $\begin{array}{c}-3.268 * * * \\
(.722)\end{array}$ & $\begin{array}{l}-1.347 \\
(2.689)\end{array}$ & $\begin{array}{l}-1.770 \\
(2.608)\end{array}$ \\
\hline Legal quality & $\begin{array}{c}-.348 \\
(1.231)\end{array}$ & & & & \\
\hline Sound money & $\begin{array}{l}-.295 \\
(.705)\end{array}$ & & & & \\
\hline Regulatory freedom & $\begin{array}{l}-2.884 * \\
(1.556)\end{array}$ & & & & \\
\hline Postcommunist & $\begin{array}{l}-2.582 \\
(3.989)\end{array}$ & $\begin{array}{c}-.960 \\
(3.726)\end{array}$ & $\begin{array}{r}6.642 \\
(4.521)\end{array}$ & $\begin{array}{l}3.505 \\
(6.127)\end{array}$ & $\begin{array}{l}6.175 \\
(6.171)\end{array}$ \\
\hline Self employment & $\begin{array}{c}.674 * * * \\
(.218)\end{array}$ & $\begin{array}{l}.816^{* * * *} \\
(.186)\end{array}$ & $\begin{array}{c}1.720^{* * * *} \\
(.289)\end{array}$ & $\begin{array}{c}2.466^{* * *} \\
(.833)\end{array}$ & $\begin{array}{c}2.556^{* * * *} \\
(.801)\end{array}$ \\
\hline $\begin{array}{l}\text { Self* government } \\
\text { size }\end{array}$ & & & & $\begin{array}{l}-.131 \\
(.167)\end{array}$ & $\begin{array}{l}-.127 \\
(.162)\end{array}$ \\
\hline Period dummies & Yes & Yes & Yes & Yes & Yes \\
\hline Observations & 140 & 140 & 140 & 140 & 111 \\
\hline Countries & 25 & 25 & 25 & 25 & 25 \\
\hline R squared & .587 & .568 & .502 & .519 & .596 \\
\hline Wald Chi / F stat & 277.63 & 271.75 & 26.72 & 27.42 & 32.79 \\
\hline First stage F stat & & & 25.84 & $14.68 / 22.35$ & $14.89 / 24.08$ \\
\hline Hansen $\mathrm{J}$ stat, $\mathrm{p}<$ & & & .772 & .453 & .828 \\
\hline
\end{tabular}

Table 3. Correlations between government indicators

\begin{tabular}{lccccc}
\hline & $\begin{array}{c}\text { Government } \\
\text { size }\end{array}$ & $\begin{array}{c}\text { Government } \\
\text { consumption }\end{array}$ & $\begin{array}{c}\text { Transfers and } \\
\text { subsidies }\end{array}$ & $\begin{array}{c}\text { Government } \\
\text { enterprise }\end{array}$ & Tax burden \\
\hline Government size & 1 & .512 & .692 & .657 & .808 \\
Government consumption & & 1 & .362 & -.061 & .292 \\
Transfers and subsidies & & & 1 & .211 & .432 \\
Government enterprise & & & & 1 & .389 \\
Tax burden & -.201 & -.099 & -.152 & -.043 & -.252 \\
Total factor productivity & & & &
\end{tabular}


Table 4. Basic estimates, determinants of total factor productivity

\begin{tabular}{|c|c|c|c|c|c|}
\hline & 1 & 2 & 3 & 4 & 5 \\
\hline Government final & $-1.136 * * *$ & $-1.719 * * *$ & $-.924 * * *$ & $-.599 * * *$ & -.342 \\
\hline consumption & $(.290)$ & $(.456)$ & $(.263)$ & $(.211)$ & $(.317)$ \\
\hline \multirow[t]{2}{*}{ Openness } & $.074 * *$ & $.113 * * *$ & $.056^{*}$ & $.109 * * *$ & $.086 * * *$ \\
\hline & $(.029)$ & $(.031)$ & $(.033)$ & $(.027)$ & $(.030)$ \\
\hline Agricultural & $-5.481 * * *$ & $-7.211 * * *$ & $-5.561 * * *$ & $-5.337 * * *$ & $-5.082 * * *$ \\
\hline employment & $(.651)$ & $(.969)$ & $(.843)$ & $(.678)$ & $(.752)$ \\
\hline Government size & $\begin{array}{l}-1.770 \\
(2.608)\end{array}$ & & & & \\
\hline $\begin{array}{l}\text { Government } \\
\text { consumption }\end{array}$ & & $\begin{array}{c}-7.211 * * * \\
(2.673)\end{array}$ & & & \\
\hline $\begin{array}{l}\text { Transfers and } \\
\text { subsidies }\end{array}$ & & & $\begin{array}{c}-5.507 * * * \\
(2.045)\end{array}$ & & \\
\hline $\begin{array}{l}\text { Government } \\
\text { enterprise }\end{array}$ & & & & $\begin{array}{l}.525 \\
(.942)\end{array}$ & \\
\hline Tax burden & & & & & $\begin{array}{c}1.596 \\
(1.467)\end{array}$ \\
\hline \multirow[t]{2}{*}{ Postcommunist } & 6.175 & $32.263 * * *$ & $11.407^{*}$ & 1.298 & 2.833 \\
\hline & $(6.171)$ & (9.686) & $(6.376)$ & $(4.855)$ & $(5.331)$ \\
\hline \multirow[t]{2}{*}{ Self employment } & $2.556 * * *$ & $1.652 *$ & .621 & $2.355 * * *$ & $2.251 * * *$ \\
\hline & $(.801)$ & $(.098)$ & $(.859)$ & $(.486)$ & $(.473)$ \\
\hline Self* government & -.127 & .234 & $24.940 * *$ & $-.126^{* *}$ & $-.161 *$ \\
\hline size indicator & $(.162)$ & $(.164)$ & (12.377) & $(.062)$ & $(.096)$ \\
\hline Period dummies & Yes & Yes & Yes & Yes & Yes \\
\hline Observations & 140 & 140 & 140 & 140 & 139 \\
\hline Countries & 25 & 25 & 25 & 25 & 25 \\
\hline $\mathrm{R}$ squared & .519 & .272 & .392 & .526 & .410 \\
\hline Wald Chi / F stat & 27.42 & 20.66 & 23.38 & 20.52 & 18.43 \\
\hline First stage F stat & $14.68 / 22.35$ & $8.50 / 9.53$ & $15.75 / 12.07$ & $18.67 / 21.53$ & $16.95 / 21.53$ \\
\hline Hansen J stat, $\mathrm{p}<$ & .453 & .875 & .876 & .523 & .572 \\
\hline
\end{tabular}


Table 5. Robustness tests

\begin{tabular}{|c|c|c|c|c|}
\hline & Minimum & Maximum & Ratio & Bootstrap \\
\hline \multirow[t]{2}{*}{ Self employment } & $1.237 * *$ & $2.240^{* * *}$ & & $1.921 * * *$ \\
\hline & $(.507)$ & $(.570)$ & & $(.532)$ \\
\hline \multirow[t]{2}{*}{ Government enterprise } & -.544 & .456 & 1.61 & .376 \\
\hline & (.798) & $(.866)$ & & $(.960)$ \\
\hline \multirow[t]{2}{*}{ Self * enterprises } & -.048 & -.129 & & $-.122 * *$ \\
\hline & $(.055)$ & $(.058)$ & & $(.056)$ \\
\hline \multirow[t]{2}{*}{ Self employment } & $1.202 * *$ & $2.171 * * *$ & & $1.882 * * *$ \\
\hline & $(.468)$ & $(.494)$ & & $(.501)$ \\
\hline \multirow[t]{2}{*}{ Taxes } & .028 & .968 & 1.63 & 1.487 \\
\hline & $(1.578)$ & $(1.516)$ & & $(1.518)$ \\
\hline \multirow[t]{2}{*}{ Self* taxes } & -015 & -.121 & & -.147 \\
\hline & $(.11538)$ & $(.099)$ & & $(.094)$ \\
\hline
\end{tabular}

Note: $* * *(* *)[*]$ denote significance at $\mathrm{p}<.01(\mathrm{p}<.05)[\mathrm{p}<.10]$. The ratios in column 3 are ratios between the minimum and maximum estimates, as evaluated at the sample mean. In both cases, the country exclusion providing the minimum effect is Mexico and that providing the maximum effect is Australia. Standard errors in column 4 are bootstrapped.

Table 6. Illustrating effects of change in entrepreneurship

\begin{tabular}{lccc}
\hline & $25^{\text {th }}$ percentile & Average & $75^{\text {th }}$ percentile \\
\hline Government enterprises & $1.432^{* * *}$ & $1.092^{* * *}$ & $.944^{* *}$ \\
& $(.389)$ & $(.365)$ & $(.377)$ \\
Tax burden & $70.6 \%$ & $53.9 \%$ & $46.5 \%$ \\
& $2.089 * * *$ & $1.789^{* * *}$ & $1.605^{* * *}$ \\
& $(.412)$ & $(.346)$ & $(.347)$ \\
\hline
\end{tabular}

Note: $* * *(* *)[*]$ denote significance at $\mathrm{p}<.01(\mathrm{p}<.05)[\mathrm{p}<.10]$, evaluated at the $25^{\text {th }}$ percentile, the sample mean, and the $75^{\text {th }}$ percentile. Numbers in italics are change as percent of a standard deviation, resulting from a one-standard deviation change of self-employment, which is approximately a five percentage point increase.

Appendix Table A1

\begin{tabular}{lclc}
\hline Country & TFP & Country & TFP \\
\hline Australia & 90.03 & Japan & 78.8252 \\
Austria & 97.08 & Mexico & 64.66338 \\
Belgium & 109.62 & Netherlands & 93.81124 \\
Canada & 90.04 & New Zealand & 68.90311 \\
Denmark & 82.28 & Norway & 95.09719 \\
Finland & 87.45 & Poland & 67.71223 \\
France & 97.31 & Portugal & 84.99915 \\
Germany & 90.31 & Spain & 100.4915 \\
Greece & 88.46 & Sweden & 99.07012 \\
Hungary & 79.71803 & Switzerland & 76.69347 \\
Iceland & 96.07635 & United Kingdom & 99.54288 \\
Ireland & 116.0325 & United States & 100 \\
Italy & 99.25532 & & \\
\hline
\end{tabular}


Figure 1. Government size and the effect of entrepreneurship

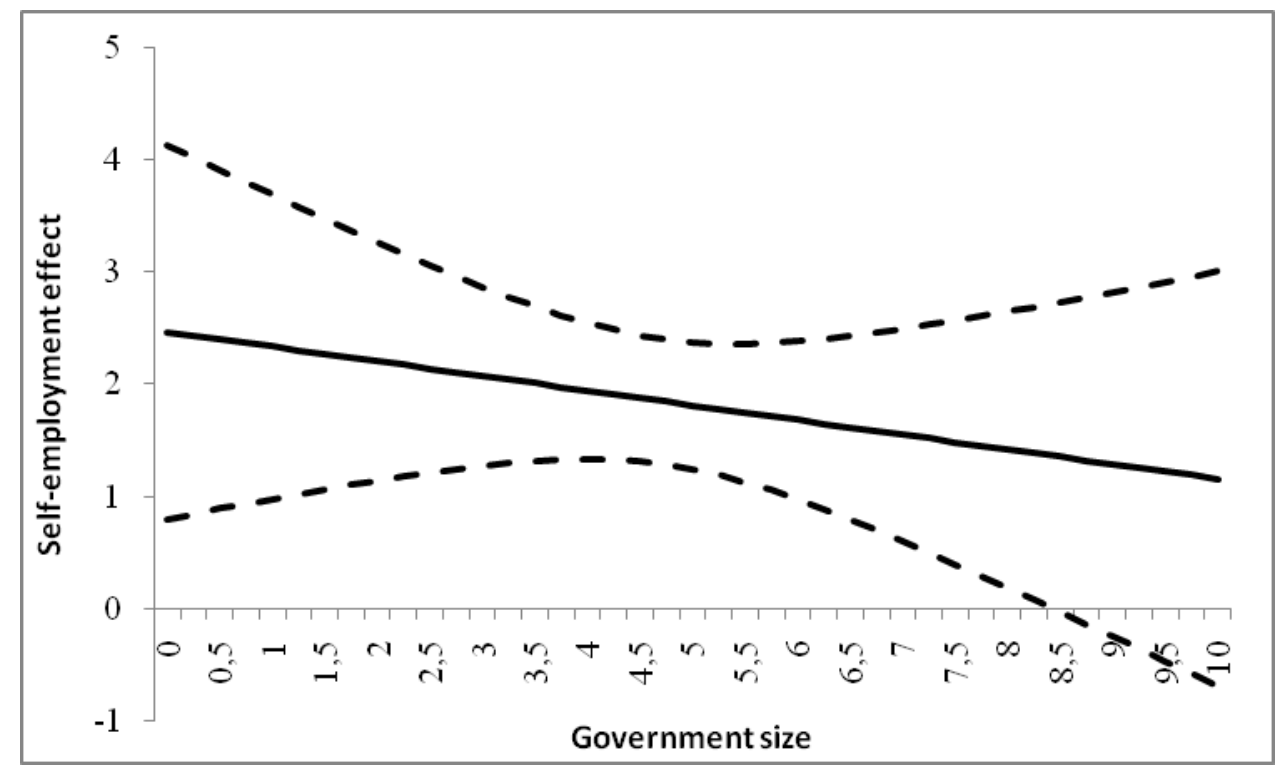


Figure 2a. Government enterprises and investment and the effect of entrepreneurship

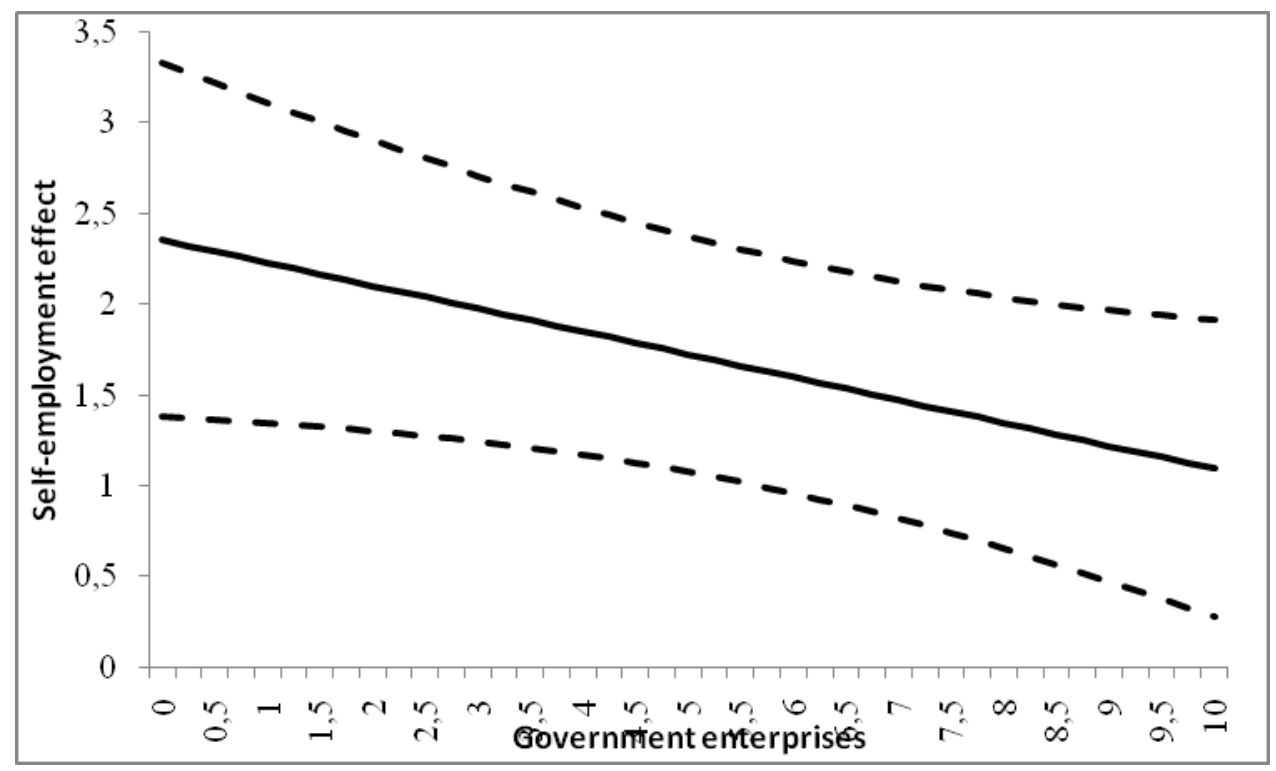

Figure 2b. Tax burdens and the effect of entrepreneurship

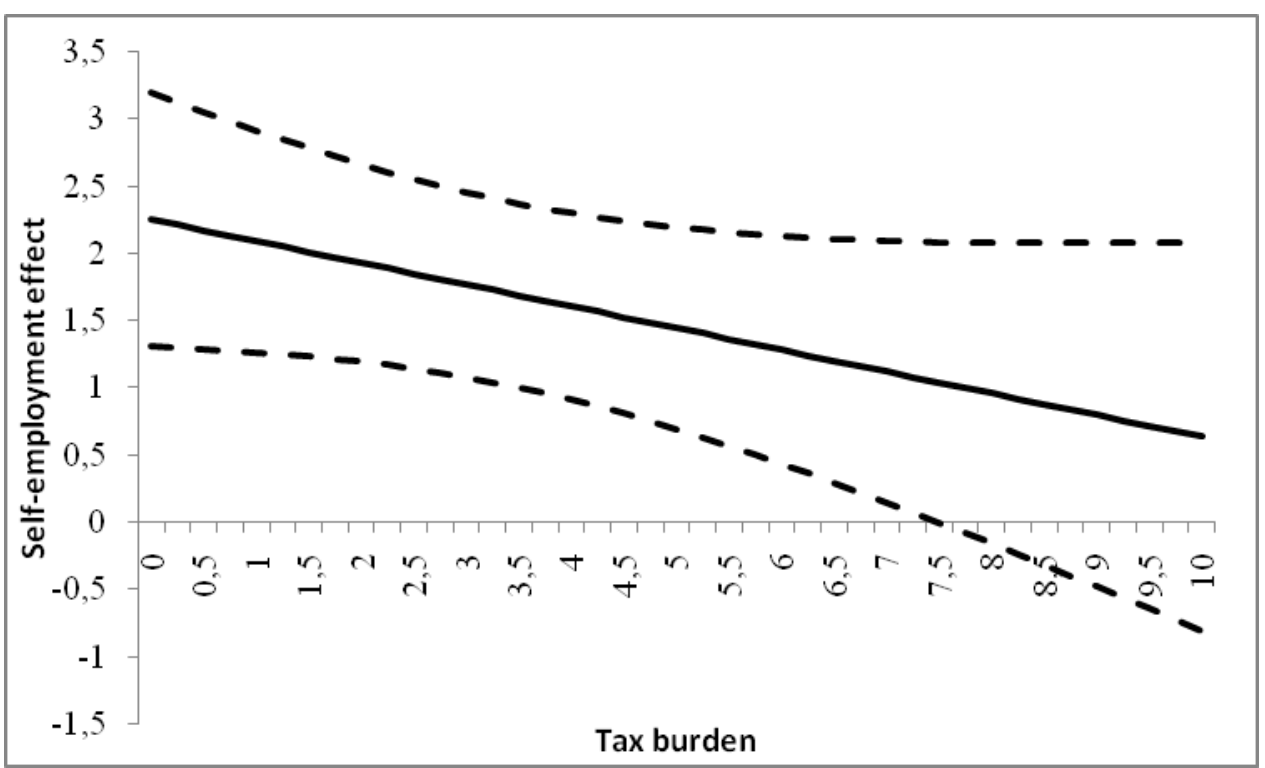




\section{SMG - Working Papers \\ www.cbs.dk/smg \\ 2003}

2003-1: Nicolai J. Foss, Kenneth Husted, Snejina Michailova, and Torben Pedersen: Governing Knowledge Processes: Theoretical Foundations and Research Opportunities.

2003-2: Yves Doz, Nicolai J. Foss, Stefanie Lenway, Marjorie Lyles, Silvia Massini, Thomas P. Murtha and Torben Pedersen: Future Frontiers in International Management Research: Innovation, Knowledge Creation, and Change in Multinational Companies.

2003-3: Snejina Michailova and Kate Hutchings: The Impact of In-Groups and OutGroups on Knowledge Sharing in Russia and China CKG Working Paper.

2003-4: Nicolai J. Foss and Torben Pedersen: The MNC as a Knowledge Structure: The Roles of Knowledge Sources and Organizational Instruments in MNC Knowledge Management CKG Working Paper.

2003-5: Kirsten Foss, Nicolai J. Foss and Xosé H. Vázquez-Vicente: “Tying the Manager's Hands": How Firms Can Make Credible Commitments That Make Opportunistic Managerial Intervention Less Likely CKG Working Paper.

2003-6: Marjorie Lyles, Torben Pedersen and Bent Petersen: Knowledge Gaps: The Case of Knowledge about Foreign Entry.

2003-7: Kirsten Foss and Nicolai J. Foss: The Limits to Designed Orders: Authority under "Distributed Knowledge" CKG Working Paper.

2003-8: Jens Gammelgaard and Torben Pedersen: Internal versus External Knowledge Sourcing of Subsidiaries - An Organizational Trade-Off.

2003-9: Kate Hutchings and Snejina Michailova: Facilitating Knowledge Sharing in Russian and Chinese Subsidiaries: The Importance of Groups and Personal Networks Accepted for publication in Journal of Knowledge Management.

2003-10: Volker Mahnke, Torben Pedersen and Markus Verzin: The Impact of Knowledge Management on MNC Subsidiary Performance: the Role of Absorptive Capacity CKG Working Paper.

2003-11: Tomas Hellström and Kenneth Husted: Mapping Knowledge and Intellectual Capital in Academic Environments: A Focus Group Study Accepted for publication in Journal of Intellectual Capital CKG Working Paper.

2003-12: Nicolai J Foss: Cognition and Motivation in the Theory of the Firm: Interaction or "Never the Twain Shall Meet"? Accepted for publication in Journal des Economistes et des Etudes Humaines CKG Working Paper.

2003-13: Dana Minbaeva and Snejina Michailova: Knowledge Transfer and Expatriation Practices in MNCs: The Role of Disseminative Capacity.

2003-14: Christian Vintergaard and Kenneth Husted: Enhancing Selective Capacity Through Venture Bases. 


\section{4}

2004-1: Nicolai J. Foss: Knowledge and Organization in the Theory of the Multinational Corporation: Some Foundational Issues

2004-2: Dana B. Minbaeva: HRM Practices and MNC Knowledge Transfer

2004-3: Bo Bernhard Nielsen and Snejina Michailova: Toward a Phase-Model of Global Knowledge Management Systems in Multinational Corporations

2004-4: Kirsten Foss \& Nicolai J Foss: The Next Step in the Evolution of the RBV: Integration with Transaction Cost Economics

2004-5: Teppo Felin \& Nicolai J. Foss: Methodological Individualism and the Organizational Capabilities Approach

2004-6: Jens Gammelgaard, Kenneth Husted, Snejina Michailova: Knowledge-sharing Behavior and Post-acquisition Integration Failure

2004-7: Jens Gammelgaard: Multinational Exploration of Acquired R\&D Activities

2004-8: Christoph Dörrenbächer \& Jens Gammelgaard: Subsidiary Upgrading? Strategic Inertia in the Development of German-owned Subsidiaries in Hungary

2004-9: Kirsten Foss \& Nicolai J. Foss: Resources and Transaction Costs: How the Economics of Property Rights Furthers the Resource-based View

2004-10: Jens Gammelgaard \& Thomas Ritter: The Knowledge Retrieval Matrix: Codification and Personification as Separate Strategies

2004-11: Nicolai J. Foss \& Peter G. Klein: Entrepreneurship and the Economic Theory of the Firm: Any Gains from Trade?

2004-12: Akshey Gupta \& Snejina Michailova: Knowledge Sharing in Knowledge-Intensive Firms: Opportunities and Limitations of Knowledge Codification

2004-13: Snejina Michailova \& Kate Hutchings: Knowledge Sharing and National Culture: A Comparison Between China and Russia

\section{5}

2005-1: Keld Laursen \& Ammon Salter: My Precious - The Role of Appropriability Strategies in Shaping Innovative Performance

2005-2: Nicolai J. Foss \& Peter G. Klein: The Theory of the Firm and Its Critics: A Stocktaking and Assessment

2005-3: Lars Bo Jeppesen \& Lars Frederiksen: Why Firm-Established User Communities Work for Innovation: The Personal Attributes of Innovative Users in the Case of Computer-Controlled Music

2005-4: Dana B. Minbaeva: Negative Impact of HRM Complementarity on Knowledge Transfer in MNCs

2005-5: Kirsten Foss, Nicolai J. Foss, Peter G. Klein \& Sandra K. Klein: Austrian Capital 
Theory and the Link Between Entrepreneurship and the Theory of the Firm

2005-1: Nicolai J. Foss: The Knowledge Governance Approach

2005-2: Torben J. Andersen: Capital Structure, Environmental Dynamism, Innovation Strategy, and Strategic Risk Management

2005-3: Torben J. Andersen: A Strategic Risk Management Framework for Multinational Enterprise

2005-4: Peter Holdt Christensen: Facilitating Knowledge Sharing: A Conceptual Framework

2005-5 Kirsten Foss \& Nicolai J. Foss: Hands Off! How Organizational Design Can Make Delegation Credible

2005-6 Marjorie A. Lyles, Torben Pedersen \& Bent Petersen: Closing the Knowledge Gap in Foreign Markets - A Learning Perspective

2005-7 Christian Geisler Asmussen, Torben Pedersen \& Bent Petersen: How do we Capture "Global Specialization" when Measuring Firms' Degree of internationalization?

2005-8 Kirsten Foss \& Nicolai J. Foss: Simon on Problem-Solving: Implications for New Organizational Forms

2005-9 Birgitte Grøgaard, Carmine Gioia \& Gabriel R.G. Benito: An Empirical Investigation of the Role of Industry Factors in the Internationalization Patterns of Firms

2005-10 Torben J. Andersen: The Performance and Risk Management Implications of Multinationality: An Industry Perspective

2005-11 Nicolai J. Foss: The Scientific Progress in Strategic Management: The case of the Resource-based view

2005-12 Koen H. Heimeriks: Alliance Capability as a Mediator Between Experience and Alliance Performance: An Empirical Investigation Into the Alliance Capability Development Process

2005-13 Koen H. Heimeriks, Geert Duysters \& Wim Vanhaverbeke: Developing Alliance Capabilities: An Empirical Study

2005-14 JC Spender: Management, Rational or Creative? A Knowledge-Based Discussion

\section{6}

2006-1: Nicolai J. Foss \& Peter G. Klein: The Emergence of the Modern Theory of the Firm

2006-2: Teppo Felin \& Nicolai J. Foss: Individuals and Organizations: Thoughts on a Micro-Foundations Project for Strategic Management and Organizational Analysis

2006-3: Volker Mahnke, Torben Pedersen \& Markus Venzin: Does Knowledge Sharing 
Pay? An MNC Subsidiary Perspective on Knowledge Outflows

2006-4: Torben Pedersen: Determining Factors of Subsidiary Development

2006-5 Ibuki Ishikawa: The Source of Competitive Advantage and Entrepreneurial Judgment in the RBV: Insights from the Austrian School Perspective

2006-6 Nicolai J. Foss \& Ibuki Ishikawa: Towards a Dynamic Resource-Based View: Insights from Austrian Capital and Entrepreneurship Theory

2006-7 Kirsten Foss \& Nicolai J. Foss: Entrepreneurship, Transaction Costs, and Resource Attributes

2006-8 Kirsten Foss, Nicolai J. Foss \& Peter G. Klein: Original and Derived Judgement: An Entrepreneurial Theory of Economic Organization

2006-9 Mia Reinholt: No More Polarization, Please! Towards a More Nuanced Perspective on Motivation in Organizations

2006-10 Angelika Lindstrand, Sara Melen \& Emilia Rovira: Turning social capital into business? A study of Swedish biotech firms' international expansion

2006-11 Christian Geisler Asmussen, Torben Pedersen \& Charles Dhanaraj: Evolution of Subsidiary Competences: Extending the Diamond Network Model

2006-12 John Holt, William R. Purcell, Sidney J. Gray \& Torben Pedersen: Decision Factors Influencing MNEs Regional Headquarters Location Selection Strategies

2006-13 Peter Maskell, Torben Pedersen, Bent Petersen \& Jens Dick-Nielsen: Learning Paths to Offshore Outsourcing - From Cost Reduction to Knowledge Seeking

2006-14 Christian Geisler Asmussen: Local, Regional or Global? Quantifying MNC Geographic Scope

2006-15 Christian Bjørnskov \& Nicolai J. Foss: Economic Freedom and Entrepreneurial Activity: Some Cross-Country Evidence

2006-16 Nicolai J. Foss \& Giampaolo Garzarelli: Institutions as Knowledge Capital: Ludwig M. Lachmann's Interpretative Institutionalism

2006-17 Koen H. Heimriks \& Jeffrey J. Reuer: How to Build Alliance Capabilities

2006-18 Nicolai J. Foss, Peter G. Klein, Yasemin Y. Kor \& Joseph T. Mahoney: Entrepreneurship, Subjectivism, and the Resource - Based View: Towards a New Synthesis

2006-19 Steven Globerman \& Bo B. Nielsen: Equity Versus Non-Equity International Strategic Alliances: The Role of Host Country Governance

\section{7}

2007-1 Peter Abell, Teppo Felin \& Nicolai J. Foss: Building Micro-Foundations for the Routines, Capabilities, and Performance Links 
2007-2 Michael W. Hansen, Torben Pedersen \& Bent Petersen: MNC Strategies and Linkage Effects in Developing Countries

2007-3 Niron Hashai, Christian G. Asmussen, Gabriel R.G. Benito \& Bent Petersen: Predicting the Diversity of Foreign Entry Modes

2007-4 Peter D. Ørberg Jensen \& Torben Pedersen: Whether and What to Offshore?

2007-5 Ram Mudambi \& Torben Pedersen: Agency Theory and Resource Dependency Theory: Complementary Explanations for Subsidiary Power in Multinational Corporations

2007-6 Nicolai J. Foss: Strategic Belief Management

2007-7 Nicolai J. Foss: Theory of Science Perspectives on Strategic Management Research: Debates and a Novel View

2007-8 Dana B. Minbaeva: HRM Practices and Knowledge Transfer in MNCs

2007-9 Nicolai J. Foss: Knowledge Governance in a Dynamic Global Context: The Center for Strategic Management and Globalization at the Copenhagen Business School

2007-10 Paola Gritti \& Nicolai J. Foss: Customer Satisfaction and Competencies: An Econometric Study of an Italian Bank

2007-11 Nicolai J. Foss \& Peter G. Klein: Organizational Governance

2007-12 Torben Juul Andersen \& Bo Bernhard Nielsen: The Effective Ambidextrous Organization: A Model of Integrative Strategy Making Processes.

\section{8}

2008-1 Kirsten Foss \& Nicolai J. Foss: Managerial Authority When Knowledge is Distributed: A Knowledge Governance Perspective

2008-2 Nicolai J. Foss: Human Capital and Transaction Cost Economics.

2008-3 Nicolai J. Foss \& Peter G. Klein: Entrepreneurship and Heterogeneous Capital.

2008-4 Nicolai J. Foss \& Peter G. Klein: The Need for an Entrepreneurial Theory of the Firm.

2008-5 Nicolai J. Foss \& Peter G. Klein: Entrepreneurship: From Opportunity Discovery to Judgment.

2008-6 Mie Harder: How do Rewards and Management Styles Influence the Motivation to Share Knowledge?

2008-7 Bent Petersen, Lawrence S. Welch \& Gabriel R.G. Benito: Managing the Internalisation Process - A Theoretical Perspective.

2008-8 Torben Juul Andersen: Multinational Performance and Risk Management Effects: Capital Structure Contingencies. 
2008-9 Bo Bernard Nielsen: Strategic Fit and the Role of Contractual and Procedural Governance in Alliances: A Dynamic Perspective.

2008-10 Line Gry Knudsen \& Bo Bernhard Nielsen: Collaborative Capability in R\&D Alliances: Exploring the Link between Organizational and Individual level Factors.

2008-11 Torben Juul Andersen \& Mahesh P. Joshi: Strategic Orientations of Internationalizing Firms: A Comparative Analysis of Firms Operating in Technology Intensive and Common Goods Industries.

2008-12 Dana Minbaeva: HRM Practices Affecting Extrinsic and Intrinsic Motivation of Knowledge Receivers and their Effect on Intra-MNC Knowledge Transfer.

2008-13 Steen E. Navrbjerg \& Dana Minbaeva: HRM and IR in Multinational Corporations: Uneasy Bedfellows?

2008-14 Kirsten Foss \& Nicolai J. Foss: Hayekian Knowledge Problems in Organizational Theory.

2008-15 Torben Juul Andersen: Multinational Performance Relationships and Industry Context.

2008-16 Larissa Rabbiosi: The Impact of Subsidiary Autonomy on MNE Knowledge Transfer: Resolving the Debate.

2008-17 Line Gry Knudsen \& Bo Bernhard Nielsen: Organizational and Individual Level Antecedents of Procedural Governance in Knowledge Sharing Alliances.

2008-18 Kirsten Foss \& Nicolai J. Foss: Understanding Opportunity Discovery and Sustainable Advantage: The Role of Transaction Costs and Property Rights.

2008-19 Teppo Felin \& Nicolai J. Foss: Social Reality, The Boundaries of Self-fulfilling Prophecy, and Economics.

2008-20 Yves Dos, Nicolai J. Foss \& José Santos: A Knowledge System Approach to the Multinational Company: Conceptual Grounding and Implications for Research

2008-21 Sabina Nielsen \& Bo Bernhard Nielsen: Why do Firms Employ foreigners on Their Top Management Teams? A Multi-Level Exploration of Individual and Firm Level Antecedents

2008-22 Nicolai J. Foss: Review of Anders Christian Hansen's “Uden for hovedstrømmen - Alternative strømninger i økonomisk teori"

2008-23 Nicolai J. Foss: Knowledge, Economic Organization, and Property Rights

2008-24 Sjoerd Beugelsdijk, Torben Pedersen \& Bent Petersen: Is There a Trend Towards Global Value Chain Specialization? - An Examination of Cross Border Sales of US Foreign Affiliates 
2008-25 Vikas Kumar, Torben Pedersen \& Alessandro Zattoni: The performance of business group firms during institutional transition: A longtitudinal study of Indian firms

2008-26 Sabina Nielsen \& Bo B. Nielsen: The effects of TMT and Board Nationality Diversity and Compensation on Firm Performance

2008-27 Bo B. Nielsen \& Sabina Nielsen: International Diversification Strategy and Firm Performance: A Multi-Level Analysis of Firm and Home Country Effects

\section{9}

2009-1 Nicolai J. Foss: Alternative Research Strategies in the Knowledge Movement: From Macro Bias to Micro-Foundations and Multi-Level Explanation

2009-2 Nicolai J. Foss \& Peter G. Klein: Entrepreneurial Alertness and Opportunity Discovery: Origins, Attributes, Critique

2009-3 Nicolai J. Foss \& Dana B. Minbaeva: Governing Knowledge: The Strategic Human Resource Management Dimension

2009-4 Nils Stieglitz \& Nicolai J. Foss: Opportunities and New Business Models: Transaction Cost and Property Rights Perspectives on Entrepreneurships

2009-5 Torben Pedersen: Vestas Wind Systems A/S: Exploiting Global R\&D Synergies

2009-6 Rajshree Agarwal, Jay B. Barney, Nicolai J. Foss \& Peter G. Klein: Heterogeneous Resources and the Financial Crisis: Implications of Strategic Management Theory

2009-7 Jasper J. Hotho: A Measure of Comparative Institutional Distance

2009-8 Bo B. Nielsen \& Sabina Nielsen: The Impact of Top Management Team Nationality Diversity and International Experience on Foreign Entry Mode

2009-9 Teppo Felin \& Nicolai Juul Foss: Experience and Repetition as Antecedents of Organizational Routines and Capabilities: A Critique of Behaviorist and Empiricist Approaches

2009-10 Henk W. Volberda, Nicolai J. Foss \& Marjorie E. Lyles: Absorbing the Concept of Absorptive Capacity: How To Realize Its Potential in the Organization Field

2009-11 Jan Stentoft Arlbjørn, Brian Vejrum Wæhrens, John Johansen \& Torben Pedersen: Produktion i Danmark eller offshoring/outsourcing: Ledelsesmæssige udfordringer 


\section{0}

2010-1 Dana B. Minbaeva, Kristiina Mäkelä \& Larissa Rabbiosi: Explaining Intraorganizational Knowledge Transfer at the Individual Level

2010-2 Dana B.Minbaeva \& Torben Pedersen: Governing Individual Knowledge Sharing Behavior

2010-3 Nicolai J. Foss \& Peter G. Klein: Alertness, Judgment, and the Antecedents of Entrepreneurship

2010-4 Nicolai J.Foss \& Joseph T.Mahoney: Exploring Knowledge Governance

2010-5 Jasper J. Hotho, Florian Becker-Ritterspach \& Ayse Saka-Helmhout: Enriching Absorptive Capacity Through Social Interaction

2010-6 Nicolai J. Foss \& Bo B. Nielsen: Researching Collaborative Advantage: Some Conceptual and Multi-level Issues

2010-7 Nicolai J. Foss \& Nils Stieglitz: Modern Resource-Based Theory(ies)

2010-8 Christian Bjørnskov \& Nicolai J. Foss: Do Economic Freedom and Entrepreneurship Impact Total Factor Productivity? 